\title{
Spinal Cord Injury in Rats Disrupts the Circadian System
}

(1) Andrew D. Gaudet, ${ }^{1,2,3,4}$ Laura K. Fonken,, ${ }^{1,2,5}$ Monica T. Ayala,, ${ }^{1,2}$ Emily M. Bateman, ${ }^{1,2}$ () Wolfgang E. Schleicher, ${ }^{1,2}{ }^{-}$Elana J. Smith, ${ }^{1,2}$ Heather M. D'Angelo, ${ }^{1,2}$ Steven F. Maier, ${ }^{1,2}$ and ${ }^{1}$ Linda R. Watkins ${ }^{1,2}$

https://doi.org/10.1523/ENEURO.0328-18.2018

${ }^{1}$ Department of Psychology and Neuroscience, University of Colorado Boulder, Boulder, Colorado $80301,{ }^{2} \mathrm{Center}$ for Neuroscience, University of Colorado Boulder, Boulder, Colorado 80301, ${ }^{3}$ Department of Psychology, College of Liberal Arts, University of Texas at Austin, Austin, Texas 78712, ${ }^{4}$ Department of Neurology, Dell Medical School, University of Texas at Austin, Austin, Texas 78712, and ${ }^{5}$ Division of Pharmacology and Toxicology, University of Texas at Austin, Austin, Texas 78712

\section{Visual Abstract}

\section{$\mathrm{SCl}$ alters several peripheral oscillators and clocks}

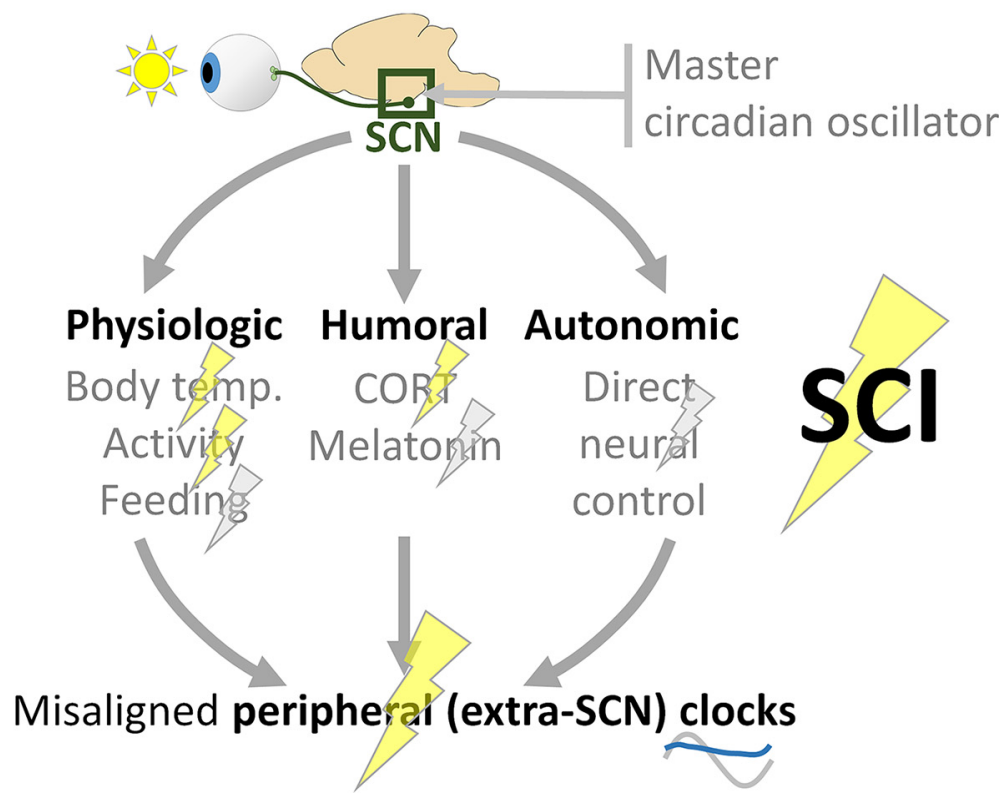

\section{Significance Statement}

Spinal cord injury (SCl) can cause physiologic dysfunction throughout the body. Internal physiologic function is typically synchronized with the environment through the circadian system. Despite the crucial roles of the spinal cord and the circadian system in optimizing whole-body function, it remains unclear whether SCl alters diurnal rhythms. Here, we hypothesized that SCI would disrupt key circadian output and feedback mechanisms. Moderate SCI in rats caused widespread disruption of diurnal measures, including glucocorticoids, body temperature, locomotor activity, and intraspinal clock and inflammatory gene expression. We identify the circadian system as a novel potential target for $\mathrm{SCl}$ therapies. 
Spinal cord injury (SCl) perturbs many physiological systems. The circadian system helps maintain homeostasis throughout the body by synchronizing physiological and behavioral functions to predictable daily events. Whether disruption of these coordinated daily rhythms contributes to $\mathrm{SCl}$-associated pathology remains understudied. Here, we hypothesized that $\mathrm{SCl}$ in rats would dysregulate several prominent circadian outputs including glucocorticoids, core temperature, activity, neuroinflammation, and circadian gene networks. Female and male Sprague Dawley rats were subjected to clinically relevant thoracic 9 moderate contusion $\mathrm{SCl}$ (or laminectomy sham surgery). Diurnal measures-including rhythms of plasma corticosterone (CORT), body temperature, and activity (using small implanted transmitters), and intraspinal circadian and inflammatory gene expression-were studied prior to and after surgery. SCl caused overall increases and disrupted rhythms of the major rodent glucocorticoid, CORT. Presurgery and sham rats displayed expected rhythms in body temperature and activity, whereas rats with $\mathrm{SCl}$ had blunted daily rhythms in body temperature and activity. In parallel, SCl disrupted intraspinal rhythms of circadian clock gene expression. Circadian clock genes can act as transcriptional regulators of inflammatory pathways. Indeed, SCI rats also showed dysregulated rhythms in inflammatory gene expression in both the epicenter and distal spinal cord. Our data show that moderate $\mathrm{SCl}$ in rats causes wide-ranging diurnal rhythm dysfunction, which is severe at acute time points and gradually recovers over time. Normalizing post-SCl diurnal rhythms could enhance the recovery of homeostasis and quality of life.

Key words: biological clock; circadian rhythms; diurnal rhythms; neurotrauma; spinal cord injury

\section{Introduction}

Spinal cord injury (SCl) dysregulates a constellation of physiologic processes throughout the body. For instance, $\mathrm{SCl}$ suppresses peripheral immunity, which increases susceptibility to infection (Schwab et al., 2014). SCI predisposes to accumulating excess adipose tissue and to metabolic syndrome (Jones et al., 2003; Cragg et al., 2015; Sauerbeck et al., 2015). In addition, SCl causes sympathetic dysfunction, which contributes to cardiovascular issues such as autonomic dysreflexia and orthostatic hypotension (Alan et al., 2010; Inskip et al., 2012). Thus, $\mathrm{SCl}$ shifts prominent body systems away from a healthy equilibrium (i.e., physiologic homeostasis).

Physiologic homeostasis is regulated by the circadian system, which synchronizes organisms to daily fluctuations in their external environment by temporally organizing internal systems (Fonken and Nelson, 2014). Circadian rhythms are endogenous free-running rhythms (persisting

Received August 22, 2018; accepted November 11, 2018; First published December 3, 2018

The authors declare no competing financial interests.

Author contributions: A.D.G., L.K.F., M.T.A., E.M.B., W.E.S., E.J.S., H.M.D., S.F.M., and L.R.W. designed research; A.D.G., M.T.A., E.M.B., W.E.S., E.J.S., and H.M.D. performed research; A.D.G. contributed unpublished reagents/ analytic tools; A.D.G., L.K.F., M.T.A., E.M.B., W.E.S., E.J.S., and H.M.D. analyzed data; A.D.G., L.K.F., and L.R.W. wrote the paper.

This work was supported by the United States Department of Defense (Grant W81XWH-13-1-0277/SC120066 to L.R.W.). Additional support was provided by Paralyzed Veterans of America (LRW: Grant 3004 to L.R.W.), the Craig H. Neilsen Foundation (to S.F.M.), and the Wings for Life Foundation (to A.D.G. and L.R.W.).

We thank the Muenzinger husbandry staff for excellent animal care; the Biological Sciences Initiative and Undergraduate Research Opportunities Program at University of Colorado Boulder for undergraduate research support; and the Light Microscopy Core Facility at the University of Colorado Boulder.

Correspondence should be addressed to Andrew D. Gaudet, Department of Psychology and Neuroscience, University of Colorado Boulder, 2860 Wilderness Place, UCB 603, Boulder, CO 80301. E-mail: andrew.gaudet@utexas.edu.

https://doi.org/10.1523/ENEURO.0328-18.2018

Copyright (C) 2018 Gaudet et al.

This is an open-access article distributed under the terms of the Creative Commons Attribution 4.0 International license, which permits unrestricted use, distribution and reproduction in any medium provided that the original work is properly attributed. even in constant darkness) lasting $\sim 24 \mathrm{~h}$ that are entrainable to external cues; when synchronized by light to day-night cycles, these rhythms are called "diurnal" rhythms. Initial circadian input occurs via light activation of retinal projections to the suprachiasmatic nucleus (SCN). SCN neurons entrain diurnal rhythms in other cells of the brain and body through neural (autonomic), humoral (e.g., glucocorticoids), and physiologic cues (external cues that coordinate biological rhythms; e.g., feeding, activity, and body temperature; Bedrosian et al., 2016). Circadian disruption can impair physiologic function, predispose to disease, and exacerbate postsurgery outcomes (Fonken et al., 2010; Li et al., 2011; Stevens et al., 2014). For example, disrupting the circadian clock with aberrantly timed light exposure following traumatic brain injury in rats increased neuronal death and cortical lesion volume, resulting in worsened sensorimotor and cognitive deficits (Li et al., 2016).

Research in rodents and humans suggests that $\mathrm{SCl}$ likely disrupts the circadian system. In mice, SCl transiently increased and disrupted daily expression rhythms of the major rodent glucocorticoid, corticosterone (CORT; Lucin et al., 2007). In rats, thoracic 3 (T3) spinal transection disrupted temperature rhythms for $\sim 14 \mathrm{~d}$ post-SCI (West et al., 2015). Together, these results imply that SCl may disrupt diurnal rhythms; however, these studies omitted sham surgery groups, which are essential given that surgery itself can disrupt these systems. Further, these studies did not explore other key circadian outputs (e.g., activity, circadian clock genes). In humans, cervical SCI disrupted diurnal body temperature rhythms at chronic times (Thijssen et al., 2011), and individuals with SCl often experience sleep disturbances (Giannoccaro et al., 2013); yet, diurnal rhythms in humans at acute-to-subacute post-SCI times remain understudied. Moreover, the existence and post-SCl regulation of a molecular circadian clock in spinal cord remains unstudied. Therefore, there is a need to understand the timing and extent of SCl-elicited circadian disruption, and how this could relate to the loss, and potential reacquisition, of physiologic homeostasis. 
Here, we hypothesized that $\mathrm{SCl}$ in rats would disrupt physiologic, behavioral, and molecular diurnal rhythms. Female and male rats with thoracic $\mathrm{SCl}$ of moderate severity displayed a strong increase in, and arrhythmia of, a major circadian entraining factor, CORT. In addition, SCI dampened daily rhythms in body temperature and activity. Moreover, spinal cords from uninjured rats displayed robust diurnal regulation of clock genes; $\mathrm{SCl}$ dysregulated intraspinal expression of clock and inflammatory genes, both in epicenter and in distal lumbar spinal cord. We reveal that clinically relevant $\mathrm{SCl}$ in rats broadly disrupts circadian function, particularly acutely postinjury.

\section{Materials and Methods}

\section{Surgery and animal care}

These experiments were approved by University of Colorado Boulder Institutional Animal Care and Use Committee and conformed with ARRIVE (Animal Research: Reporting In Vivo Experiments) standards. In agreement with National Institutes of Health guidelines, male and female rats were included in all experiments. Rats had standard chow and filtered tap water available ad libitum and were maintained on a $12 \mathrm{~h}$ light/dark cycle. All surgeries occurred between zeitgeber time 2 (ZT2) and ZT11. Sprague Dawley sham/SCl rats (females, $200-250 \times$ g; males, 320-380 $\times$ g; 2-3 months old; Envigo) received isoflurane anesthesia and a T8 laminectomy; $\mathrm{SCl}$ rats additionally received a moderate contusion injury (midline SCl; 150 kdyn, 1 s dwell; Infinite Horizon, Precision Systems and Instrumentation). Initial related studies involved pain testing, and inflammation was also studied, so analgesics were not given to any rats for consistency and for limiting confounds (Detloff et al., 2008; Cho et al., 2009; Ellis et al., 2016; Grace et al., 2016). All rats received prophylactic and postsurgery intraperitoneal antibiotics (gentamicin sulfate), subcutaneous saline for $5 \mathrm{~d}$ postinjury (dpi), and post-SCl bladder voiding twice daily (Gaudet et al., 2015, 2017).

\section{Tissue processing, histology, and analysis}

To evaluate lesion size and spared tissue area, tissue was collected for immunohistochemistry $(n=7$ male and female rats) at $7 \mathrm{dpi}$. Rats received an intraperitoneal pentobarbital overdose and were transcardially perfused with $0.9 \%$ saline, then $4 \%$ paraformaldehyde. Spinal cords were suspended in paraformaldehyde overnight, cyroprotected in 30\% sucrose, and cryosectioned (16 $\mu \mathrm{m}$; Gaudet et al., 2015). For immunohistochemistry, slides were incubated with $10 \%$ normal donkey serum $(1 \mathrm{~h})$, then with primary antibodies (overnight; mouse anti-glial fibrillary acidic protein (GFAP; 1:100; catalog \#0869110, MP-Biomedicals) and rabbit anti-lba1 (1:1000; catalog \#019-19741, Wako Chemicals), then with secondary antibodies (2 h; Alexa Fluor-488 donkey anti-mouse (A-21202) and Alexa Fluor-546 donkey anti-rabbit (A10040); both 1:500; Thermo Fisher Scientific) and DAPI (nuclear stain; catalog \#D1306, Thermo Fisher Scientific). Images were captured on an Olympus IX81 Microscope and analyzed using Fiji (Schindelin et al., 2012).

\section{Locomotor testing}

Locomotor recovery was assessed using the Basso, Beattie, and Bresnahan (BBB) scale (Basso et al., 1995; female sham: $n=6$; $\mathrm{SCl}, n=5$; male sham: $n=7$; $\mathrm{SCl}$, $n=5$ ) by two condition-blind observers before surgery; and at $1,4,7,10,14,21,28,35$, and 42 d postsurgery.

\section{Collection and measurement of plasma corticosterone}

Rats were pair housed; cage mates had the same surgery (at start: female sham: $n=6$; SCl, $n=10$; male sham: $n=6$; SCI, $n=10$; two female and one male SCI rat died). Rats were acclimated to handling for $5 \mathrm{~d}$; then, blood samples were collected from immobilized unanesthetized rats via tail nick $(<500 \mu \mathrm{L} / 24 \mathrm{~h})$. Blood was collected presurgery, and 2, 7, and $14 \mathrm{~d}$ postsurgery at ZT0, ZT6, ZT12, and ZT18 (starting at ZTO; CORT was typically the lowest). For dark-phase collections, dim red light headlamps were used (Fonken and Nelson, 2014). Samples were centrifuged $(10,000 \times g ; 10 \mathrm{~min})$ to isolate plasma. Plasma was used in a CORT ELISA (catalog \#ADI-901-097, Enzo). Several samples (various rats and time points) had insufficient plasma, so were excluded, and samples that took longer than 3 min to collect were excluded (due to confounding stress-elicited CORT).

\section{Body temperature and locomotor activity measurement}

Individually housed rats were implanted intraperitoneally with radiotelemetric transmitters (MiniMitter, Respironics; Fonken et al., 2012). After a 1 week recovery, prelaminectomy baseline activity/temperature was recorded for 1 week. Home cages on 12 TR-4000 receiver boards linked with DP-24 DataPorts (MiniMitter) continuously collected temperature/activity. Activity and body temperature were recorded for $>6$ weeks postsurgery.

Female and male experiments were completed separately due to a limited number of telemetry receivers. First, males [sham, $n=6$; $\mathrm{SCl}, n=5$ (originally 6 ); one $\mathrm{SCl}$ rat transmitter did not transmit] were tested. Including shams was important: basic surgeries can disturb circadian rhythms (Farr et al., 1988). Sham/SCl rats received daily handling postsurgery (twice-daily bladder emptying or handling for shams; at approximately ZT2 and ZT10) and daily antibiotic/saline injections for $5 \mathrm{~d}$ postsurgery (approximately ZT2). Two weeks postsurgery, rats voided bladders independently, and daily checks continued without handling. After the male experiment, the experimental design was improved. For females (sham, $n=6$; SCI, $n=$ 6), presurgery handling (twice per day) acclimated the rats and reduced potential stress effects on postsurgery activity/temperature. Postsurgery antibiotic/saline injections (for 5 d postsurgery) occurred at afternoon (ZT10) animal care to limit the disruption of key early inactive phase rhythms.

\section{Diurnal regulation of gene expression}

For the uninjured PCR study, tissues were collected from uninjured female/male rats across the day (ZT0, ZT6, $\mathrm{ZT} 12$, and ZT18; $n=6 /$ sex/time point). Rats received an intraperitoneal pentobarbital overdose then were per- 
Table 1: Primer sequences and related function of assessed RNAs

\begin{tabular}{|c|c|c|}
\hline Gene & Protein function & Primer sequences $\left(5^{\prime}\right.$ to 3 ) \\
\hline b-actin & Housekeeping control & $\begin{array}{l}\text { F: TTCCTTCCTGGGTATGGAAT } \\
\text { R: GAGGAGCAATGATCTTGATC }\end{array}$ \\
\hline Bmal1 & $\begin{array}{l}\text { Circadian clock gene, with Clock, activates } \\
\text { Per and Cry transcription }\end{array}$ & $\begin{array}{l}\text { F: AAAATGCAAGGGAGGCCCAC } \\
\text { R: TCTAACTTCCGGGACATCGC }\end{array}$ \\
\hline Clock & $\begin{array}{l}\text { Circadian Clock gene, with Bmal1, } \\
\quad \text { activates Per and Cry transcription }\end{array}$ & $\begin{array}{l}\text { F: CTGCTGACAAAAGCCAAGAT } \\
\text { R: GACTITCTTGAGCTTCTGGA }\end{array}$ \\
\hline Cry1 & $\begin{array}{l}\text { Circadian Clock gene, with } P e r \text {, } \\
\text { represses Bmal and Clock transcription }\end{array}$ & $\begin{array}{l}\text { F: GTGGTGGCGGAAACTGCTCTC } \\
\text { R: ACTCTGTGCGTCCTCTTCCTGA }\end{array}$ \\
\hline Per1 & $\begin{array}{l}\text { Circadian Clock gene, with } C r y \text {, } \\
\text { represses Bmal and Clock transcription }\end{array}$ & $\begin{array}{l}\text { F: GTGCAGGCTAACCAGGAATA } \\
\text { R: GCGGAGAGTGTATTCAGATG }\end{array}$ \\
\hline Per2 & $\begin{array}{l}\text { Circadian Clock gene, with Cry, } \\
\text { represses Bmal and Clock transcription }\end{array}$ & $\begin{array}{l}\text { F: ACAAGCGGCTGCAGTAGTGA } \\
\text { R: TTCAAGGTTGCCAGCGTGCT }\end{array}$ \\
\hline Rev-erba (Nr1d1) & $\begin{array}{l}\text { Circadian Clock gene represses expression } \\
\text { of core clock proteins }\end{array}$ & $\begin{array}{l}\text { F: AGACGCTGTGCGTTTTGGAC } \\
\text { R: TGTGGGAACTGAGAGAAGCC }\end{array}$ \\
\hline Cd68 & $\begin{array}{l}\text { Inflammation expressed by microglia/macrophages; activation } \\
\text { marker; cell homing and adhesion }\end{array}$ & $\begin{array}{l}\text { F: CAAGCAGCACAGTGGACATTC } \\
\text { R: CAAGAGAAGCATGGCCCGAA }\end{array}$ \\
\hline $\begin{array}{l}\text { lba1 } \\
\text { (AIF1) }\end{array}$ & $\begin{array}{l}\text { Inflammation expressed by all microglia/macrophages; increased } \\
\text { with activation; binds calcium and actin }\end{array}$ & $\begin{array}{l}\text { F: GGCAATGGAGATATCGATAT } \\
\text { R: AGAATCATTCTCAAGATGGC }\end{array}$ \\
\hline$I L-1 b$ & $\begin{array}{l}\text { Proinflammatory cytokine; secreted mainly by } \\
\text { microglia/macrophages }\end{array}$ & $\begin{array}{l}\text { F: CCTTGTGCAAGTGTCTGAAG } \\
\text { R: GGGCTTGGAAGCAATCCTTA }\end{array}$ \\
\hline IL-6 & $\begin{array}{l}\text { Cytokine with mixed proinflammatory and anti-inflammatory } \\
\text { roles }\end{array}$ & $\begin{array}{l}\text { F: AGAAAAGAGTTGTGCAATGGCA } \\
\text { R: GGCAAATTTCCTGGTTATATCC }\end{array}$ \\
\hline Mhc II & $\begin{array}{l}\text { Membrane-bound receptor; expressed by antigen-presenting cells } \\
\text { (including microglia and macrophages); presents antigens }\end{array}$ & $\begin{array}{l}\text { F: AGCACTGGGAGTTTGAAGAG } \\
\text { R: AAGCCATCACCTCCTGGTAT }\end{array}$ \\
\hline Tnfa & $\begin{array}{l}\text { Proinflammatory cytokine; secreted mainly by } \\
\text { microglia/macrophages }\end{array}$ & $\begin{array}{l}\text { F: CAAGGAGGAGAAGTTCCCA } \\
\text { R: TTGGTGGTTTGCTACGACG }\end{array}$ \\
\hline
\end{tabular}

F, Forward; R, reverse.

fused with $0.9 \%$ saline. Tissues were flash frozen for PCR (L4-L5 was used for uninjured spinal cord analyses; T8 (lesion) and L4-L5 were used for postsurgery analyses). L4-L5 was used as a distal spinal cord site because it integrates hindpaw nociceptive information, which could provide useful information for future studies. L4-L5 was used for the uninjured analyses, since the T8 injury site was expected to have major shifts in gene expression (SCI vs sham, given that the lesion was present), whereas the lumbar spinal cord was predicted to have more minor SCl-elicited changes. For the sham/SCI PCR study, female/male rats received sham/SCI surgery $(n=6 /$ sex, except for lumbar spinal cord, $n=4$ /sex; 2 d postsurgery collection). Before surgery, rats were handled to minimize postsurgery bladder care stress. SCl rats received postsurgery bladder care, and sham rats received similar handling (control for stress); the bladder care immediately before tissue collection was omitted to limit circadian disruption. Tissue from sham/SCl rats was collected at mid-light phase (ZT6; 48 h postsurgery) and at mid-dark phase (ZT18; $\sim 60 \mathrm{~h}$ postsurgery) at $2 \mathrm{~d}$ postsurgery. Tissue collections were completed within $1-2 \mathrm{~h}$ of the time point (e.g., ZT6; tissue collected at ZT5-ZT7). Subgroups of males and females were collected on the same days to minimize between-day differences and to enable sex comparisons.

Quantitative real-time PCR was completed as described previously (Fonken et al., 2018). Primers (Invitrogen) spanned exons (Table 1, for sequences). Gene expression was assessed in duplicate and is presented relative to $\beta$-actin. There were no significant differences in $\beta$-actin expression between groups, and male, female, sham, and $\mathrm{SCl}$ rat samples were all run on the same plates to ensure consistency. PCR results were analyzed using $2^{-\Delta \Delta C t}$ and normalized with female sham-ZT6 set to 1 .

\section{Statistics}

Data were analyzed (SigmaPlot 13.0, SYSTAT) using Student's $t$ test or nonparametric Mann-Whitney $U$ test; or ANOVAs (one-, two-, or three-way ANOVA, as appropriate). Holm-Sidak post hoc tests were completed when appropriate for all tests involving more than two groups. Circadian data were analyzed using Circ Wave (https:// www.euclock.org/results/item/circ-wave.html), which assesses independent circadian data (i.e., one individual contributes to a single data point) to identify waveforms and acrophases (rhythm peaks). Twice-daily postsurgery handling (voiding/injections) caused stress-elicited hyperthermia and hyperactivity in all groups and were excluded from Circ Wave analyses for clarity. Activity data were also analyzed using ClockLab 6.0 (Actimetrics); actograms and wavelets were assessed for each rat, and data from representative male sham and $\mathrm{SCl}$ individuals are presented. Actograms were scaled between 0 and 30 . Researchers were blind to experimental group. Data were significant when $p<0.05$. Data were plotted as the mean \pm SEM.

\section{Results}

\section{T8 spinal cord contusion (150 kdyn, $1 \mathrm{~s}$ dwell) causes tissue pathology and locomotor deficits}

First, we examined tissue damage in male and female rats at $7 \mathrm{dpi}$ in this SCI model (Gaudet et al., 2017; Fig. 1). 
$-1280 \mu \mathrm{m}$
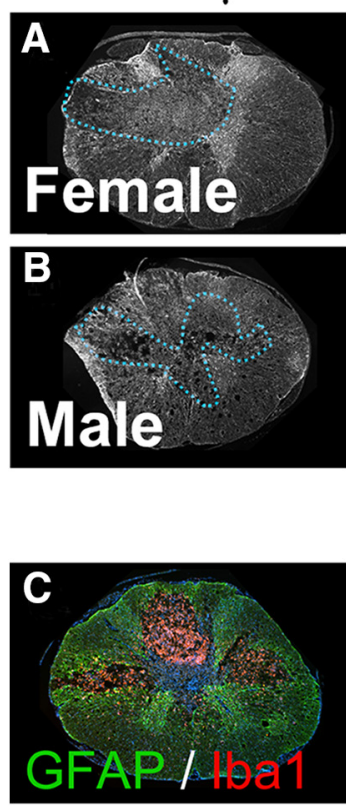
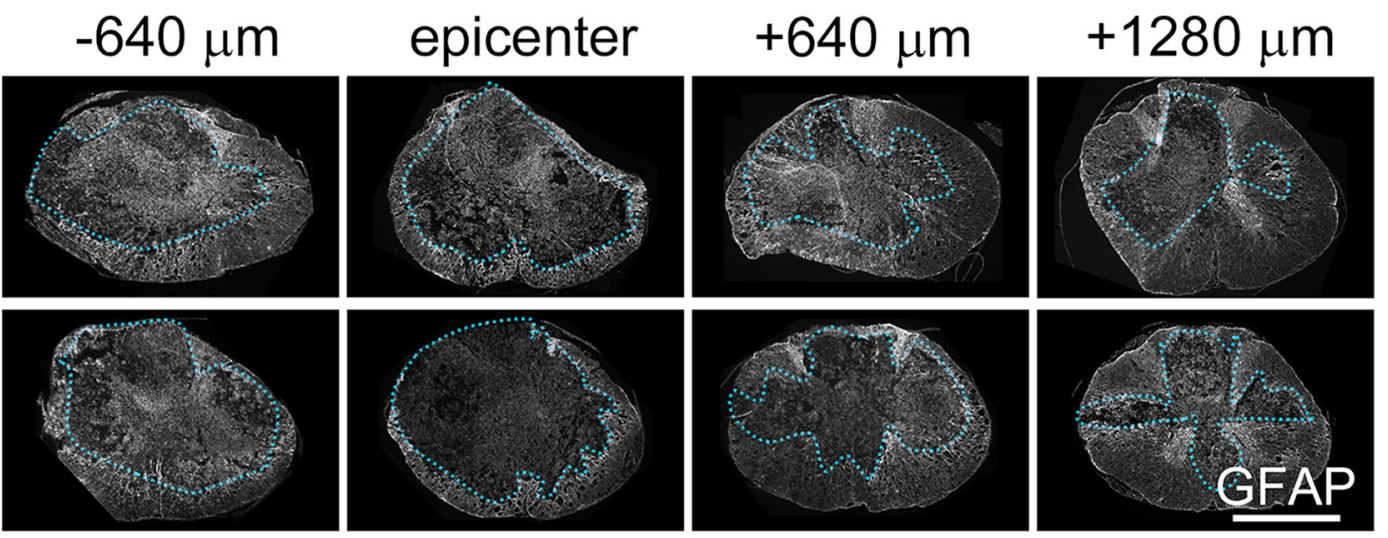

D lesion size

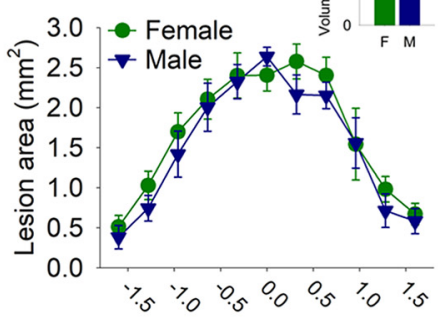

Distance from epicenter $(\mathrm{mm})$
E spared tissue

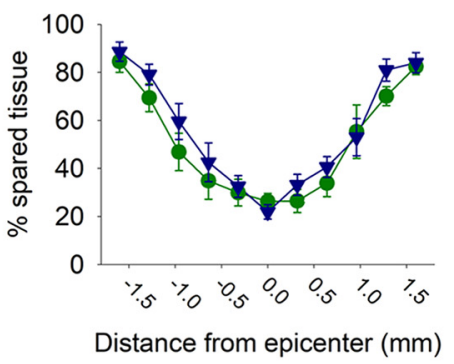

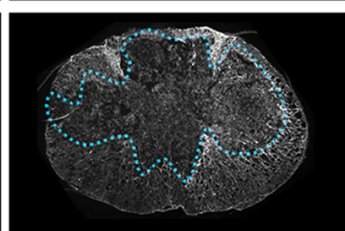

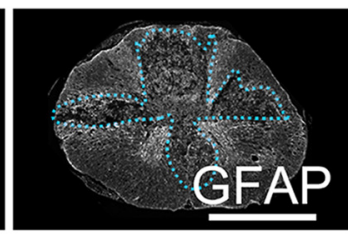

F locomotor function

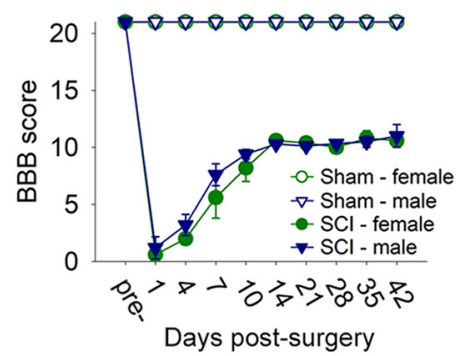

Figure 1. T9 contusion $\mathrm{SCl}$ (150 kdyn, $1 \mathrm{~s}$ dwell) causes extensive tissue loss at/near the epicenter with associated locomotor impairment. $\boldsymbol{A}, \boldsymbol{B}$, Spinal cords from female $(\boldsymbol{A})$ and male $(\boldsymbol{B})$ rats show substantial pathology and cavitation at $7 \mathrm{~d}$ post-SCl. GFAP immunoreactivity was used to visualize and assess tissue pathology; dotted lines outline the approximate lesion border in each section. C, Example of GFAP (astrocytes, green) and lba1 (microglia/macrophages, red) immunoreactivity in the 7 dpi lesion site (blue, nuclei; DAPI). GFAP ${ }^{+}$astrocytes form the glial scar; Iba1 ${ }^{+}$macrophages/microglia exist in the epicenter and $\mathrm{Iba}^{+} \mathrm{microglia}$ are present in the lesion penumbra. $\boldsymbol{D}, \boldsymbol{E}$, Analysis of lesion area and volume $(\boldsymbol{D})$ and the percentage spared tissue $(\boldsymbol{E})$ at $7 \mathrm{~d}$ post-SCI. There were no significant sex differences in lesion size or the percentage of spared tissue. $\boldsymbol{F}$, Moderate T9 SCI caused substantial immediate locomotor deficits in female and male rats that recovered over time, as assessed in an open field using the BBB scale. There were no significant differences in BBB scores between female and male SCl rats. Scale bar, $1 \mathrm{~mm}$.

As expected, substantial tissue loss was observed at the T8 lesion epicenter (Fig. 1D); moving rostrocaudally away from the epicenter, there was progressively more tissue sparing (Fig. 1E). There were no significant differences in lesion size or tissue sparing in females versus males (lesion volume: females, $8.15 \pm 0.70 \mathrm{~mm}^{3}$; males, $7.48 \pm$ $\left.0.46 \mathrm{~mm}^{3} ; p>0.05\right)$.

Locomotor recovery after sham/SCl was assessed (Fig. $1 F$ ). At $1 \mathrm{dpi}$, average BBB scores indicated that $\mathrm{SCl}$ rats had movement of one hindlimb joint. By $42 \mathrm{dpi}, \mathrm{SCl}$ rats recovered frequent hindlimb stepping with no (or little) coordination (females: BBB score, $10.6 \pm 0.6$; males: BBB score, $11.0 \pm 1.4$ ).

\section{Spinal cord injury causes a transient increase and arrhythmia in plasma CORT}

CORT release is regulated in a circadian manner; this steroid hormone maintains metabolic homeostasis across the day and helps to entrain extra-SCN circadian rhythms (Nicolaides et al., 2014). Here, we assessed whether SCl dysregulated plasma CORT levels and rhythms (Fig. 2). Before surgery, female and male rats showed peak trough patterns in plasma CORT (Fig. 2A; D'Agostino et al., 1982): CORT had cycle peak (acrophase) near early to mid-active phase (at approximately ZT12; females, ZT12: $1.4 \pm 0.3 \mathrm{ng} / \mathrm{ml}$; males, ZT12: $0.6 \pm 0.1 \mathrm{ng} / \mathrm{ml}$ ), and was lowest at the start of the inactive phase (ZTO; females: 0.6 $\pm 0.2 \mathrm{ng} / \mathrm{ml}$; males: $0.4 \pm 0.1 \mathrm{ng} / \mathrm{ml})$. CORT levels were higher overall in presurgery females than males (Cavigelli et al., 2005). In females, CORT was unusally high at ZT6, which could have been related to a handling-elicited CORT increase (Gärtner et al., 1980). CORT was expressed rhythmically before injury in both females $\left(F_{(2,37)}\right.$ $=3.465, p<0.05)$ and males $\left(F_{(2,33)}=6.647, p<0.005\right)$.

$\mathrm{SCl}$ disrupted typical rhythms and significantly increased CORT levels at acute postinjury times (females: main effect of injury: $F_{(3,62)}=3.606, p<0.05$; males: main effect of injury: $\left.F_{(3,70)}=22.584, p<0.001\right)$. Females with $\mathrm{SCl}$ had increased CORT at $7 \mathrm{dpi}$ (vs presurgery; at ZTO; $p<0.05$ ); males with $\mathrm{SCl}$ showed significant CORT increases at 2 dpi (vs presurgery; at ZTO and ZT6; $p<$ 0.001 ) and 7 dpi (at ZTO; $p<0.05$; Fig. 2B). For average CORT concentration across the day, $\mathrm{SCl}$ in female and male rats caused significant increases in average CORT at 2 d postsurgery (females: vs presurgery, $p<0.05$; males: main effect of surgery; also at 2 dpi vs both presurgery and sham, $p<0.001$; Fig. $2 C$ ).

\section{Spinal cord injury alters daily rhythms in body temperature}

Body temperature and activity are two prominent outputs of the circadian system that also help to entrain 

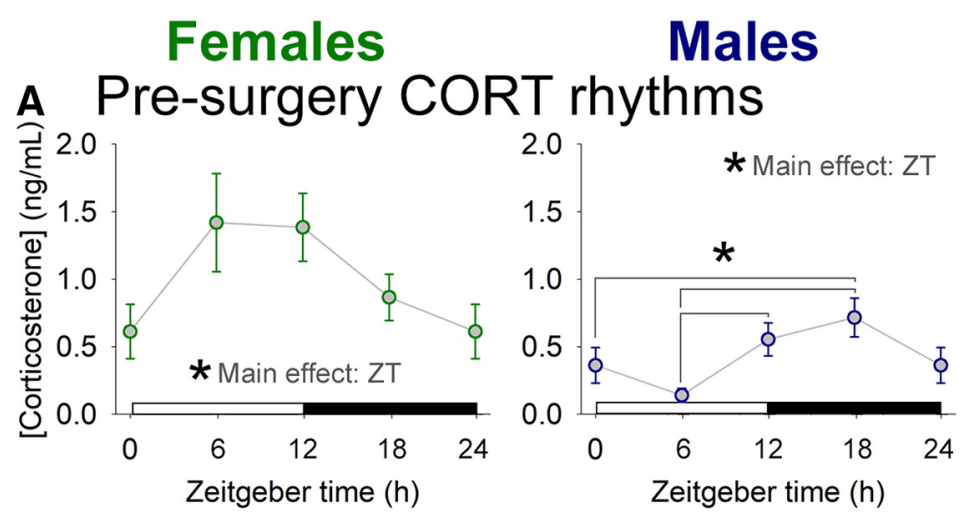

\section{B CORT rhythms}
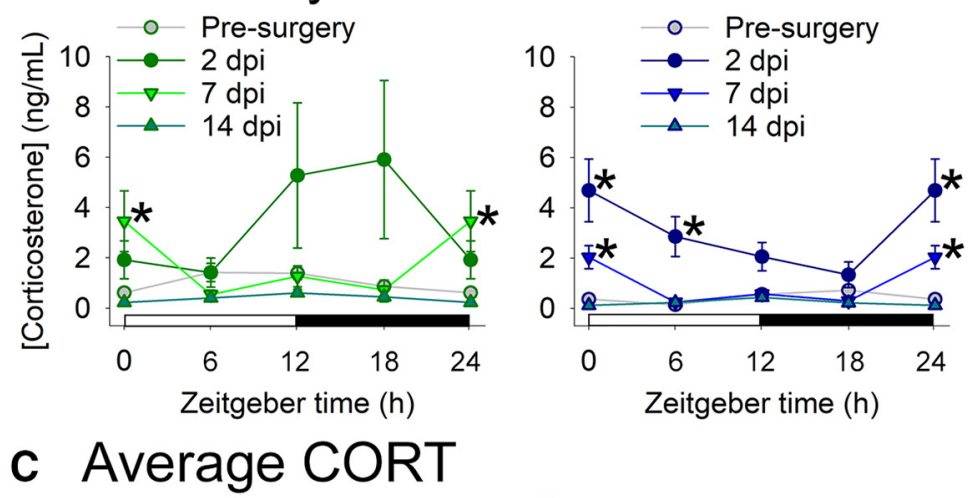

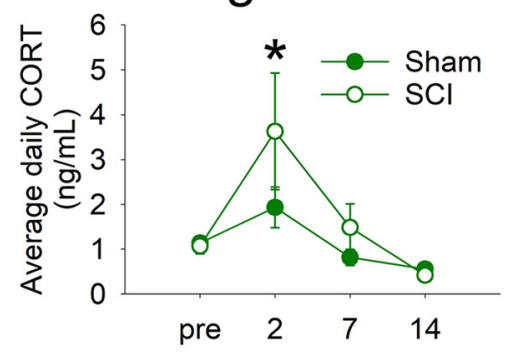

Days post-surgery

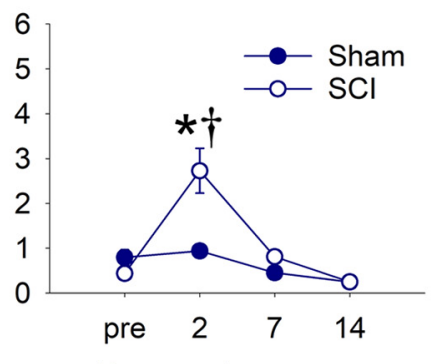

Days post-surgery

Figure 2. $\mathrm{SCl}$ in female and male rats disrupts diurnal rhythms in CORT. A, Before surgery, female and male rats exhibited diurnal rhythms in CORT, with nadir levels at the beginning of the inactive (light) phase and peak levels toward the beginning of the active (dark) phase. B, SCl increased CORT levels and altered CORT rhythms at 2 and $7 \mathrm{dpi}$; CORT rhythms were normalized by 14 dpi. $\boldsymbol{C}$, Average CORT level across the day in female and male SCl rats was increased at 2 dpi. *ZT differences or SCl vs presurgery, ANOVA with Holm-Sidak post hoc test, $p<0.05$; †SCl vs sham at that time point, $p<0.05$.

circadian rhythms in cells throughout the body (Reebs and Mrosovsky, 1989; Buhr et al., 2010). To measure these parameters, rats were implanted with a small transmitter and were studied before sham/SCl, and from acute-to-chronic times postsurgery. (The studies on male and female rats were completed consecutively, due to the limited number of telemetry receivers; for details, see Materials and Methods.)

Before surgery, female and male rats displayed the expected diurnal rhythms in body temperature: core temperature was higher during the active phase, and lower during the inactive phase (female-SCl presurgery acrophase, ZT16.6; male-SCl presurgery acrophase, ZT17.3; Fig. 3). Immediately after surgery (i.e., after replacing postsurgery rats on transmitter boards), $\mathrm{SCl}$ but not sham rats experienced hypothermia (lasted $\sim 18 \mathrm{~h}$; ANOVA main effect: female: $F_{(1,155)}=31.664, p<0.001$; male: $F_{(1,142)}=24.663, p<0.001$; and significant differences at specific times; Fig. 3).

After initial post-SCI hypothermia, female rats showed significant $\mathrm{SCl}$-elicited temperature dysregulation. By $2 \mathrm{~d}$ postsurgery, female sham and $\mathrm{SCl}$ rats both showed approximately typical rhythms in core temperature (Circ Wave; all showed rhythmicity). Compared with sham rats, female SCl rats had shifted (advanced) acrophases between 2 and $6 \mathrm{~d}$ postsurgery and increased inactive phase temperatures between 2 and $5 d$ postsurgery (2- $6 \mathrm{~d}$ sham acrophases: ZT15.5, ZT15.7, ZT14.9, and ZT15.9, respectively; 2-6 dpi SCl acrophases: ZT12.0, ZT12.9, ZT13.0, and ZT14.5, respectively; ANOVA of main effect of treatment and injury-time interaction, 2-3 d postsurgery: $F_{(1,203)}=6.678, p<0.05$; sham vs SCl, 2 d postsurgery: 
Females

Pre-surgery

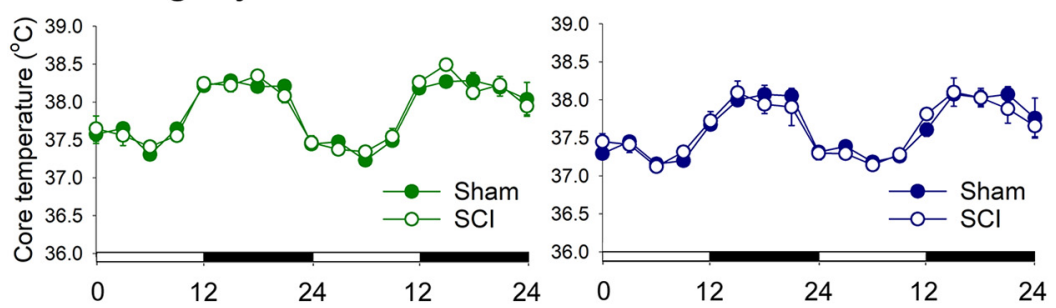

immed. post-surgery
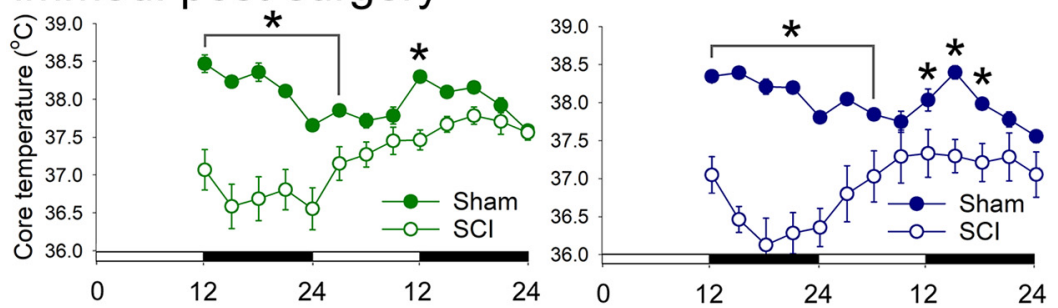

2-3 d post-surgery
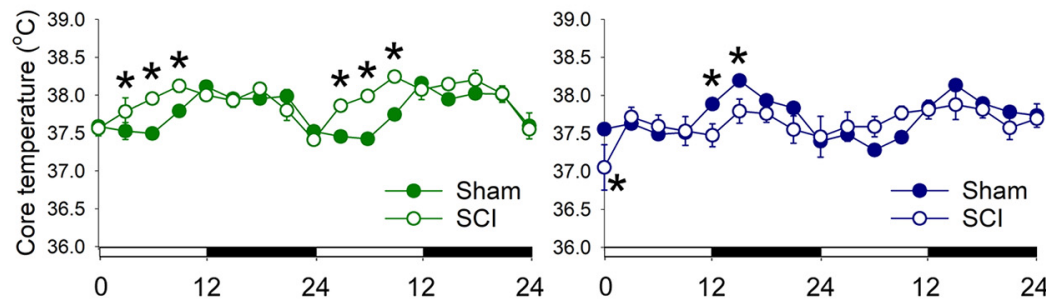

4-5 d post-surgery
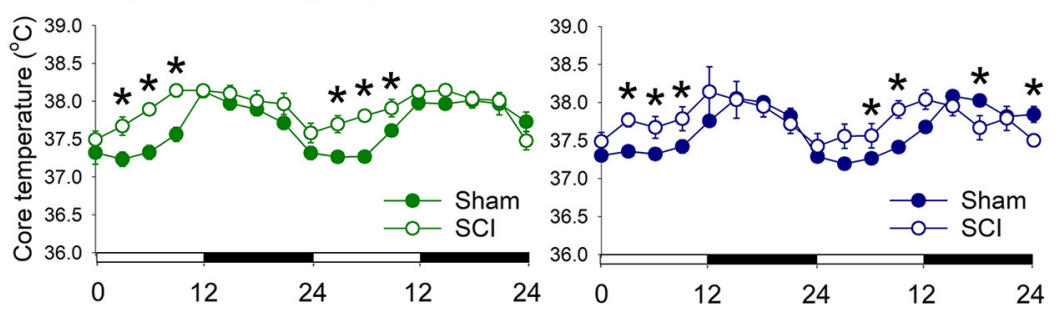

6-7 d post-surgery
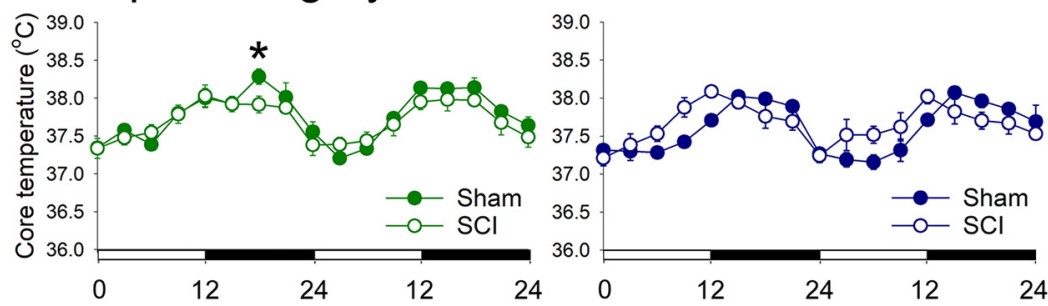

\section{3-14 d post-surgery}
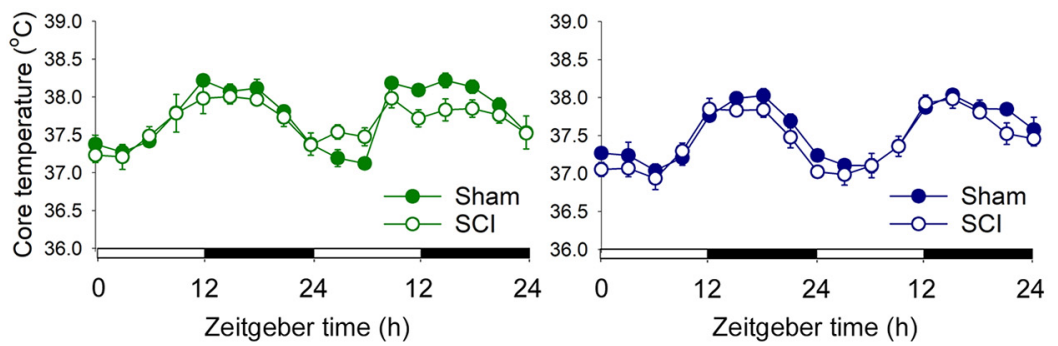

Figure 3. $\mathrm{SCl}$ in female and male rats disrupted diurnal rhythms of core body temperature. Before surgery, female and male rats exhibited typical diurnal core temperature rhythms. Immediately after surgery, SCI rats displayed hypothermia. SCI disrupted diurnal 
continued

rhythms in core temperature between 2 and $5 \mathrm{~d}$ postsurgery. Diurnal temperature regulation was similar between sham and SCl rats by $13-14$ d postsurgery. $* p<0.05$ for sham vs SCl at that time point, ANOVA with Holm-Sidak post hoc test.

ZT3, ZT6, and ZT9; 3 d postsurgery: ZT3, ZT6, and ZT9, $p$ $<0.05$; 4-5 d postsurgery: $F_{(1,203)}=12.207, p<0.01$; sham vs SCl: 6 d postsurgery: ZT18, $p<0.05$; inactive phase temperature: $\mathrm{SCl}>$ sham, $15 \mathrm{~d}$ postsurgery, $p<$ $0.05)$. $\mathrm{SCl}$ rats displayed no significant differences versus sham at 7,13 , or $14 \mathrm{~d}$ postsurgery ( $7 \mathrm{dpi}$ : ANOVA, no main effect of treatment, $F_{(1,203)}=0.982 ; 13-14$ dpi: ANOVA, no main effect of treatment, $\left.F_{(1,203)}=1.147, p>0.05\right)$.

Male rats showed a similar pattern to females of SClelicited temperature dysregulation, but with somewhat delayed recovery of rhythms. Sham rats at 2-3 dpi showed approximately typical rhythms in core temperature ( 2 and 3 d postsurgery sham acrophases: ZT13.3 and ZT16.2; all showed rhythmicity); conversely, male SCI rats at 2-3 dpi did not have significant core temperature rhythms (ANOVA main effect of treatment: $F_{(1,186)}=0.688$, $p>0.05)$. Male $\mathrm{SCl}$ rats displayed shifted acrophases and increased inactive phase temperatures compared with sham rats between 4 and 5 d postsurgery (acrophases: sham, 4 d postsurgery: 16.4; SCl, 4 dpi: 13.7; sham, 5 d postsurgery: 16.4; SCl, 5 dpi: 12.5; ANOVA main effect of treatment: $F_{(1.186)}=0.657, p>0.05$; inactive phase temperature: $\mathrm{SCl}>$ sham, $4-5$ d postsurgery, $p<0.05$ ). There were no significant differences caused by $\mathrm{SCl}$ in core temperature at 6-7 d postsurgery (ANOVA, no main effect of treatment: $\left.F_{(1,186)}=0.400, p>0.05\right)$ nor at $13-14$ d postsurgery (ANOVA, no main effect of treatment: $\left.F_{(1,186)}=2.794, p>0.05\right)$.

To understand more broadly whether $\mathrm{SCl}$ influenced temperature rhythms, daily temperature was processed in ClockLab in grouped multiday "bins" (Fig. 4). Before surgery, the peak daily temperature phase occurred in females at an angle of $263.5^{\circ}$ (or ZT17.8) and in males at $275.2^{\circ}$ (or ZT18.3). After surgery, females with SCI showed no significant difference in phase from shams $(p$ $>0.05$, two-way repeated-measures ANOVA with Holm-
Sidak post hoc test). In contrast, males with SCI displayed significantly advanced temperature phases: $\mathrm{SCl}$ males had earlier temperature acrophase starting at 2-5 d postsurgery [ANOVA main effect of treatment: $F_{1,81}=43.299$, $p<0.001 ; 2-5$ d postsurgery: male sham rats, phase angle $261.9^{\circ} \pm 3.4^{\circ}$ (ZT17.5); male SCl rats, phase angle $208.3 \pm 15.3^{\circ}$ (ZT13.9); $p<0.05$ ], and these SCl advanced rhythms continued through all $5 \mathrm{~d}$ bins examined through 26-30 d postsurgery [26-30 d postsurgery: male sham rats, phase angle $268.7 \pm 4.9^{\circ}$ (ZT17.9); male SCI rats, phase angle $249.9 \pm 4.1^{\circ}$ (ZT16.7); $\left.p<0.05\right]$. At 31-35 d postsurgery and beyond, male $\mathrm{SCl}$ rat temperature acrophases were not significantly different from those of male sham rats [e.g., 31-35 d postsurgery: male sham rats, $269.5 \pm 3.5^{\circ}$ (ZT18.0); male SCl rats, $257.2 \pm 4 .^{\circ}$ (ZT17.1); $p>0.05$ ].

Overall, $\mathrm{SCl}$ altered the average core temperature at early postinjury times-particularly due to increased temperature during the inactive phase-and showed substantial recovery at subacute times. $\mathrm{SCl}$ males (vs females) displayed significant and longer-lasting shifts in temperature acrophase.

\section{Spinal cord injury disrupts amount and diurnal rhythms of activity}

Activity patterns are a strong index of the integrity of the circadian system. Although $\mathrm{SCl}$ clearly reduces activity, it is also possible that it disrupts activity rhythms. Rhythmic activity is important for entraining peripheral circadian rhythms (Reebs and Mrosovsky, 1989; Tahara et al., 2017). Before surgery, rats showed typical diurnal patterns of activity, with more activity during the active phase (female SCl rats presurgery acrophase, ZT15.1; male SCI rats presurgery acrophase, ZT17.9; counts in active phase: females, $65 \pm 2 \%$; males, $67 \pm 2 \%$ ).

\section{Temperature peak: phase angle}

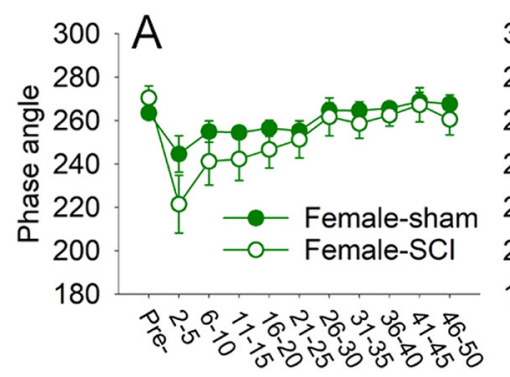

Days post-surgery

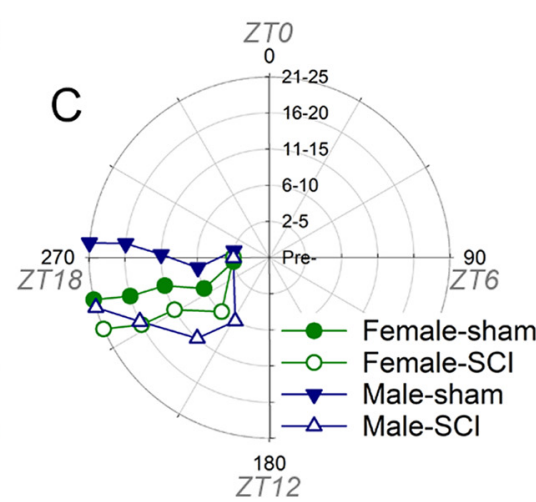

Figure 4. SCl significantly advanced temperature acrophase in males, but not females. Temperature phase angles (in bins of $4-5 \mathrm{~d}$ ) were studied in female and male rats before surgery, then up to $50 \mathrm{~d}$ postsurgery. $\boldsymbol{A}$, Compared with sham rats, females with $\mathrm{SCl}$ showed no significant difference in phase angle after surgery. $\boldsymbol{B}, \mathrm{SCl}$ males had significantly advanced temperature acrophases from 2-5 d through 26-30 d postsurgery. C. Phase plot showing how SCl affected the phase angle over time postsurgery (up to $25 \mathrm{~d}$ for clarity). Angle indicates the time of acrophase; radial distance depicts time postsurgery. $* p<0.05$. 
After surgery, differences in activity between sham and $\mathrm{SCl}$ rats occurred mainly during the active phase (Fig. 5). Sham rats showed relatively typical activity levels and diurnal activity rhythms by 2-3 d postsurgery ( 2 and $3 \mathrm{~d}$ postsurgery sham acrophases: female, ZT15.2 and ZT16.2; male, ZT15.8 and ZT16.8). In contrast, female and male $\mathrm{SCl}$ rats had strongly reduced activity throughout the day at 2 dpi (total counts: female sham rats, 13,000 \pm 2000; female SCI rats, $7000 \pm 2000 ; p<0.05$; male sham rats, $13,200 \pm 800$; male SCl rats, $3200 \pm 800 ; p<$ $0.001)$. Although this pattern of post-SCl reduced activity continued for days, there was some recovery of diurnal activity rhythms over the first $5 \mathrm{dpi}$. At 6-7 dpi, female and male rats with $\mathrm{SCl}$ showed further recovery of activity, but not $6 \mathrm{dpi}$, although their overall activity remained significantly lower than that of sham rats. Patterns of activity at $6 \mathrm{~d}$ postsurgery and beyond were not significantly different between sham and $\mathrm{SCl}$ rats in both females and males (percentage counts in active phase at $6 \mathrm{~d}$ postsurgery: female sham rats, $70 \pm 2 \%$; female SCl rats, $63 \pm 3 \% ; p$ $>0.05$; male sham rats, $70 \pm 2 \%$; male SCl rats, $62 \pm$ $3 \% ; p>0.05)$.

At 13-14 d postsurgery, female and male SCl rats had activity patterns that were more similar to shams (acrophases: female sham rats, 13.9; female $\mathrm{SCl}$ rats, 13.3; male sham rats, 16.2; male SCI rats, 15.8; total counts in active phase at 14 dpi: female sham rats, $9000 \pm 900$; female SCI rats, $7000 \pm 1000 ; p>0.05$; male sham rats, $8500 \pm 500$; male SCI rats, $6600 \pm 500 ; p<0.05$ ). These patterns were even more similar at a chronic post-SCI time point (acrophases: female sham rats, 15.8; female $\mathrm{SCl}$ rats, 15.7; male sham rats, 16.1 ; male $\mathrm{SCl}$ rats, 15.5). Therefore, SCI transiently dampens activity levels, and the timing of post-SCl recovery of daily activity counts and rhythms parallels the recovery of other circadian measures.

\section{Spinal cord injury delays recovery of $24 \mathrm{~h}$ activity rhythms}

To establish postsurgery latency to recovery of $24 \mathrm{~h}$ activity rhythms, actogram and wavelet analyses were performed. These qualitative assessments help visualize diurnal rhythms. Data from one male sham rat and one male $\mathrm{SCl}$ rat (both representative) are presented. Before surgery, the rats displayed expected rhythms in activity (Fig. 6A). After sham surgery, rats recovered relatively typical rhythms within $\sim 1 \mathrm{~d}$ postsurgery. In contrast, after $\mathrm{SCl}$, rats recovered $24 \mathrm{~h}$ activity rhythms approximately 6-7 d postsurgery (Fig. 6B,C, yellow arrows). Therefore, $\mathrm{SCl}$ substantially delayed the recovery of diurnal activity rhythms.

\section{Spinal cord injury disrupts clock gene expression in epicenter and lumbar spinal cord}

Rhythms of circadian "clock" gene expression exist throughout the body; however, clock gene expression has not been systematically characterized in the spinal cord. Thus, first we sought to establish how clock genes are regulated by time of day in the uninjured rat spinal cord (Fig. 7A). Our data reveal that clock genes are expressed rhythmically in the L4-L5 spinal cord. The "core clock" components Per2, Cry 1 , and Bmal1 were all regulated in spinal cord by time and sex [Cry1, Bmal1: main effect of time $(p<0.001)$ and sex (females $>$ males, $p<0.001$ ); Per2: significant time-sex interaction, $F_{3,44}=2.953, p<$ $0.05]$ and were expressed rhythmically across the day (all in both females and males; acrophases: Per2: female, ZT15.2 \pm 1.2; male, ZT12.2 \pm 1.2; Cry1: female, ZT16.3 \pm 1.4; male, ZT16.8 \pm 1.5; Bmal1: female, ZT23.0 \pm 1.4; male, ZT0.8 \pm 1.3). Similarly, Rev-erb $\alpha$, a transcription factor in a secondary circadian feedback loop, was regulated in spinal cord by time of day (interaction with sex: $\left.F_{(3,44)}=3.953, p<0.05\right)$ and was rhythmically expressed (in females and males; Rev-erb $\alpha$ acrophases: female, ZT6.0 \pm 1.4 ; male, ZT6.6 \pm 1.1 ).

To establish whether $\mathrm{SCl}$ alters molecular circadian rhythms, rats were subjected to T8 sham (laminectomy) or $\mathrm{SCl}$ surgery, and tissue was collected at $2 \mathrm{~d}$ postsurgery in the light (ZT6) or dark (ZT18) phase. Clock gene expression was assessed in T8 epicenter and lumbar spinal cord (Fig. 7B,C). In T8 epicenter, SCl (vs sham surgery) substantially downregulated key clock genes Per2, Cry1, Bmal1, and Rev-erb $\alpha\left(F_{(1,45)}=45.7,113.2,82.1\right.$, and 135.6, respectively; all $p<0.001$; main effect at ZT6 and ZT18; Fig. 7B). In addition, there were time-of-day differences in sham rats that were abolished by $\mathrm{SCl}$ in several genes (Per2, Cry1, and Rev-erb $\alpha$; post hoc test), and there were sex differences in Cry 1 and Rev-erb $\alpha$ expression (main effect; males higher).

Dysregulation of circadian genes by $\mathrm{SCl}$ extended beyond the lesion site. Lumbar spinal cord from SCl (vs sham) rats displayed significantly reduced expression of Per2, Cry1, Bmal1, and Rev-erb $\alpha\left(F_{(1,30)}=40.7\right.$, 48.4, 62.2 , and 23.8, respectively; all $p<0.001$, all main effects; $\mathrm{SCl}$ also downregulated Per2 at ZT6 and ZT18; Fig. 7C). In addition, there were main effects on clock gene expression of time (Cry1, Bmal1, and Rev-erb $\alpha$ ) and sex (Per2, Cry1, and Bmal1). Additional clock genes dysregulated by SCl included Per1 and Clock (Table 2).

\section{Spinal cord injury disrupts inflammatory gene expression in epicenter and lumbar spinal cord}

Inflammatory genes in the CNS can also be regulated by time of day, and this likely confers differential immunocompetence across the day (Fonken et al., 2015). In the healthy adult rat spinal cord, several inflammatory genes were expressed differentially across the day (Fig. $8 A$ ): the proinflammatory cytokines $I L-1 b$ (main effect of time: $F_{(3,43)}=3.54, p<0.05$; females had significant daily rhythm, $p<0.05)$ and Tnfa (main effect of time: $F_{(3,44)}=$ 5.57, $p<0.005$; males had significant daily rhythm, $p<$ 0.01 ); the inflammatory cytokine $I L-6$ (main effect of time: $F_{(1,44)}=6.99, p<0.001$; males had significant daily rhythm, $p<0.005$ ); and the microglial/macrophage activation marker Cd68 (significant interaction of time and sex: $F_{(3,44)}=5.51, p<0.005$; males had significant daily rhythm, $p<0.005)$.

$\mathrm{SCl}$ significantly dysregulated inflammatory gene expression in epicenter and lumbar spinal cord (main effects; Fig. 8B,C). IL-1b was significantly upregulated in $\mathrm{SCl}$ (vs sham) rats in the T8 lesion epicenter but was 


\section{Pre-surgery}

Females

Males

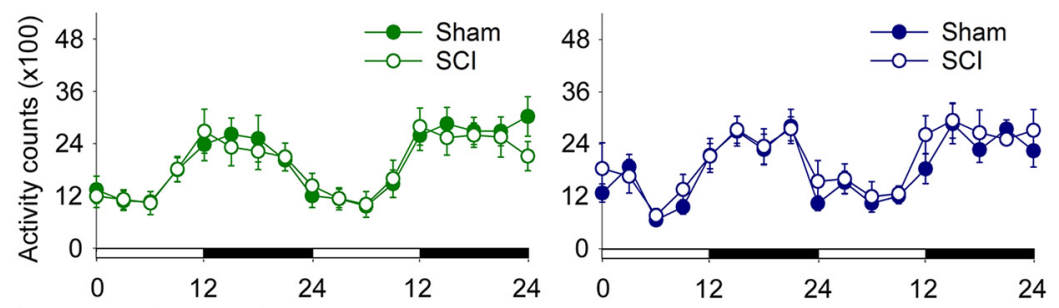

Immed. post-surgery
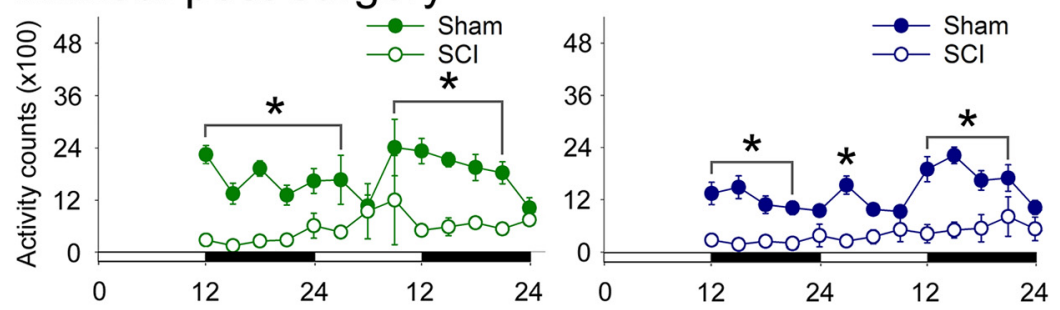

2-3 d post-surgery
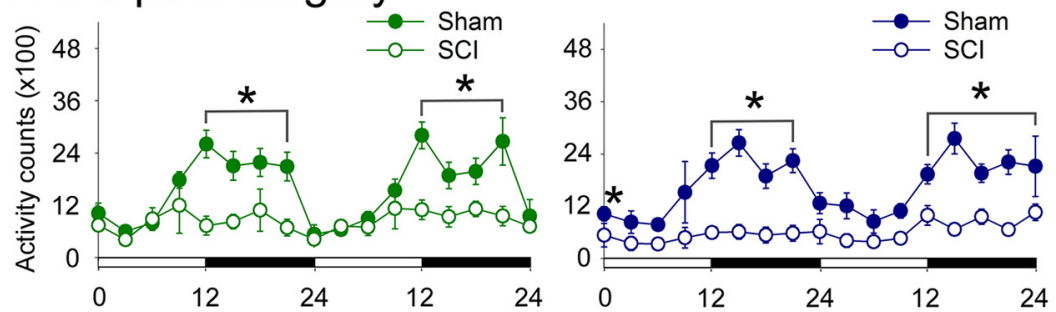

4-5 d post-surgery
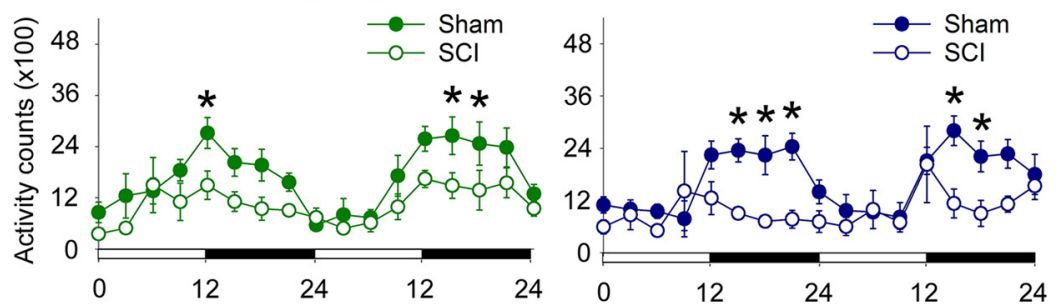

6-7 d post-surgery
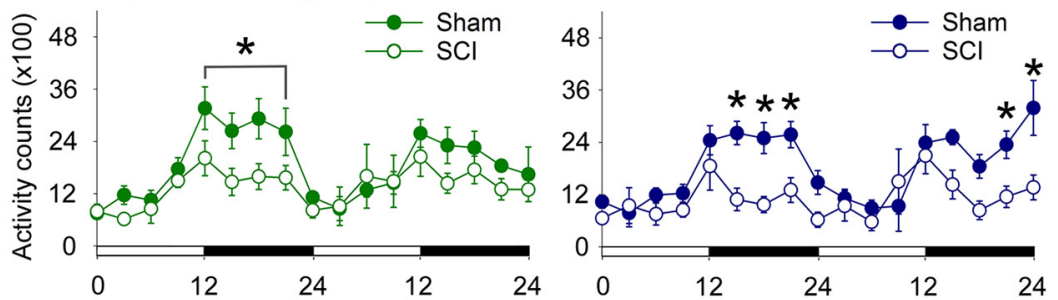

\section{3-14 d post-surgery}
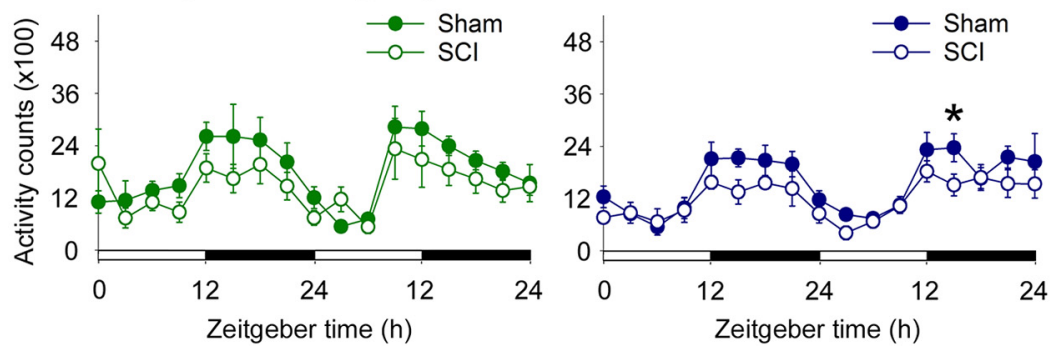

Figure 5. $\mathrm{SCl}$ in female and male rats disrupted diurnal rhythms in activity. Data show cumulative activity counts per $3 \mathrm{~h}$ time period. Before surgery, female and male rats exhibited typical diurnal rhythms in activity, with rats more active in the dark phase. As expected, 
continued

$\mathrm{SCl}$ rats were less active at acute times postinjury (up to $7 \mathrm{~d}$ postsurgery). Interestingly, at subacute (14 d postsurgery) to chronic times, $\mathrm{SCl}$ rats regained activity levels and diurnal rhythms in activity that were similar to those of sham rats. $* p<0.05$ for sham vs $\mathrm{SCl}$ at that time point, ANOVA with Holm-Sidak post hoc test.

downregulated in the lumbar spinal cord $\left(F_{(1,45)}=11.9\right.$ and $F_{(1,30)}=144.7$, respectively; both $p<0.001$; main effects). Tnfa was upregulated by $\mathrm{SCl}$ in both the epicenter and the lumbar spinal cord $\left(F_{(1,45)}=12.9\right.$ and $F_{(1,29)}=$ 7.9 , respectively; both $p<0.001$; main effects; also main effect of time: lumbar). IL-6 expression was increased in $\mathrm{SCl}$ rats in the epicenter, but was reduced in the lumbar spinal cord $\left(F_{(1,44)}=43.6, p<0.001 ; F_{(1,29)}=4.5, p<\right.$ 0.05 , respectively; main effects; also main effect of sex in both tissues). Cd68 expression was increased by $\mathrm{SCl}$ in
A

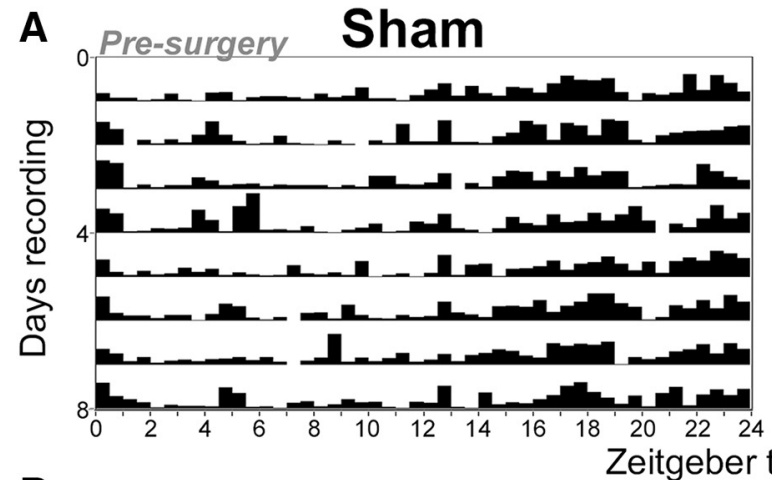

B
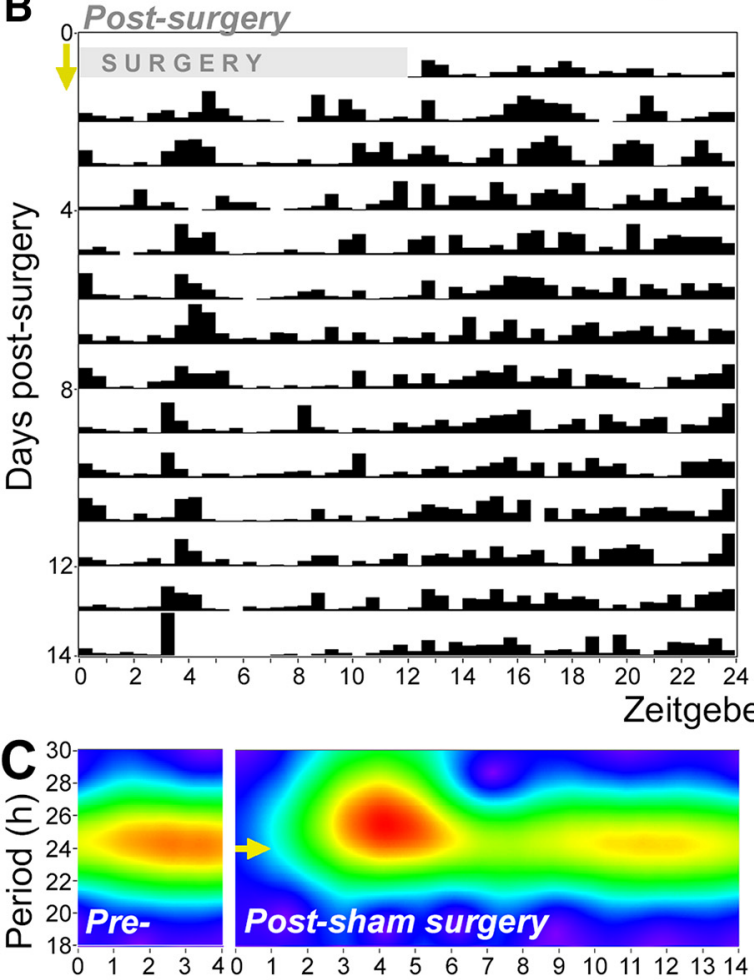

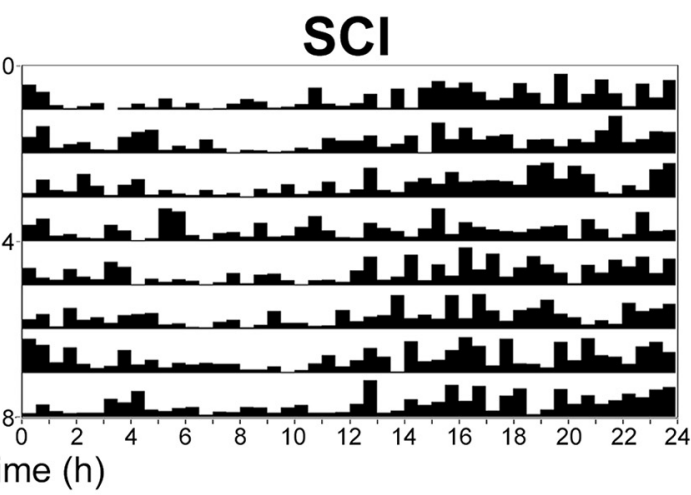

$\mathrm{SCl}$

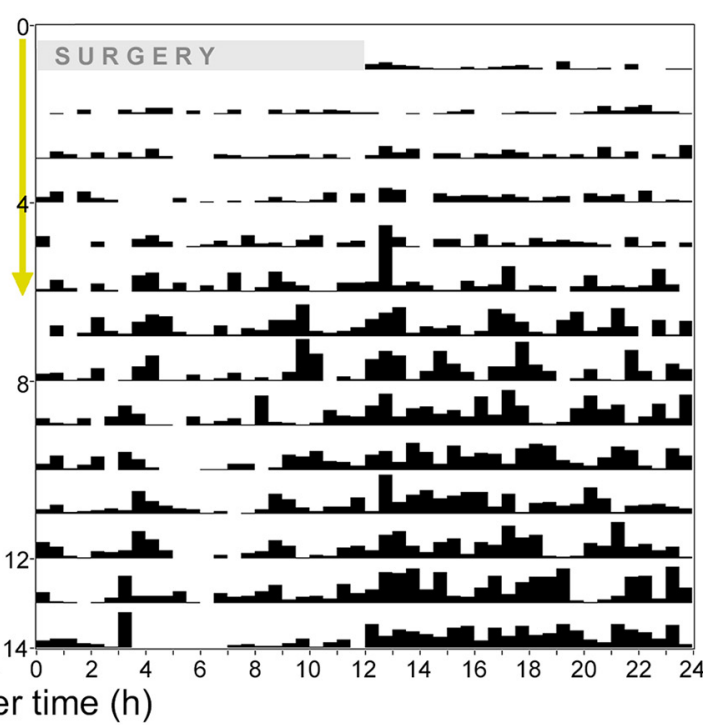

Days recording

Figure 6. Rats with $\mathrm{SCl}$ show delayed the recovery of diurnal activity rhythms. These representative data are from one male sham and one male $\mathrm{SCl}$ rat. $\boldsymbol{A}, \boldsymbol{B}$, Actograms display continuous measures of activity across the day (ZT; $x$-axis) and over time postsurgery ( $y$-axis). A, Before surgery, these rats in the sham and $\mathrm{SCl}$ groups had expected diurnal patterns of activity (i.e., increased activity between ZT12 and ZT24; higher black bars). $\boldsymbol{B}$, After surgery, sham rats quickly recover more typical activity rhythms, whereas SCI rats show delayed postsurgery recovery of rhythms. Yellow arrows highlight approximate latency to the recovery of $24 \mathrm{~h} \mathrm{rhythms;} \mathrm{also}$ shown in $\boldsymbol{C}$. $\boldsymbol{C}$, Wavelet analysis shows that before surgery rats display strong $24 \mathrm{~h}$ rhythms, and that sham and $\mathrm{SCl}$ rats have different postsurgery latencies to recover $24 \mathrm{~h}$ activity rhythms (yellow arrows). The sham rat recovered $24 \mathrm{~h}$ rhythms within $\sim 1 \mathrm{~d}$ postsurgery, whereas the $\mathrm{SCl}$ rat recovered $24 \mathrm{~h}$ rhythms at $\sim 6 \mathrm{~d}$ postsurgery. The intensity of rhythm across days is represented by the color continuum: purple (minimal rhythm) through blue and green to red (intense rhythm). 
A Uninjured: spinal cord
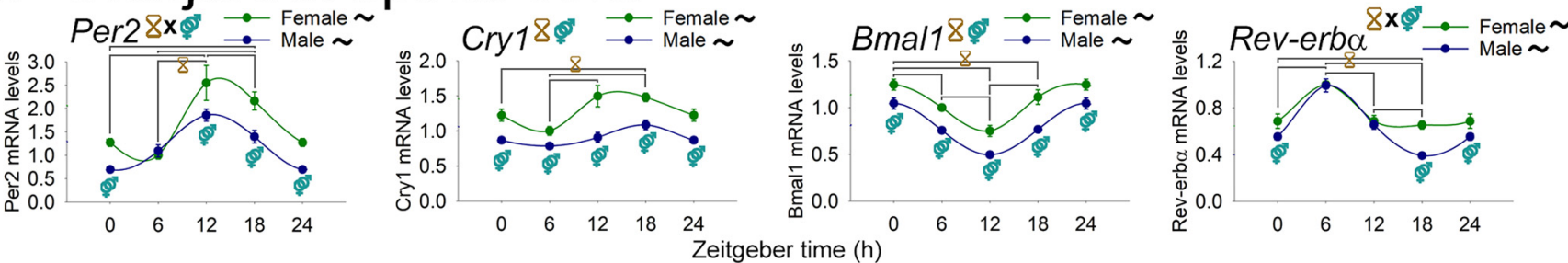

\section{B 2 d post-surgery: lesion epicenter}
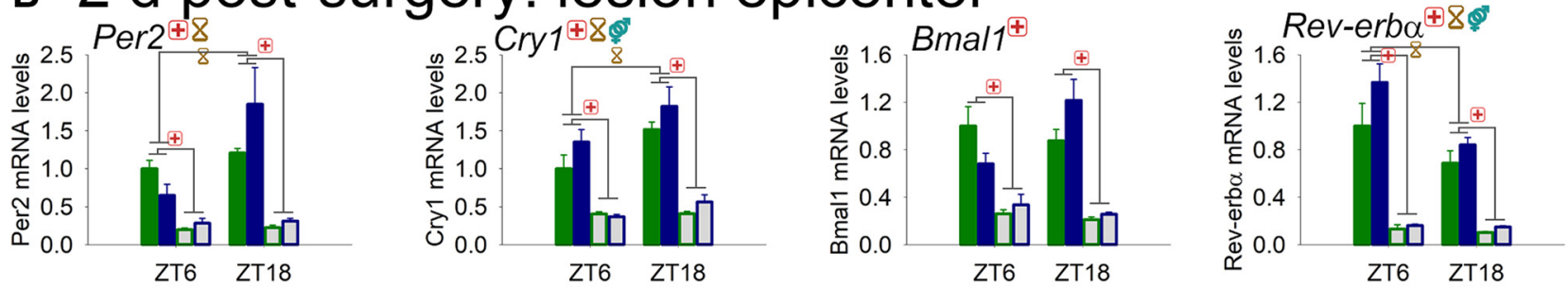

\section{c 2 d post-surgery: lumbar spinal cord}
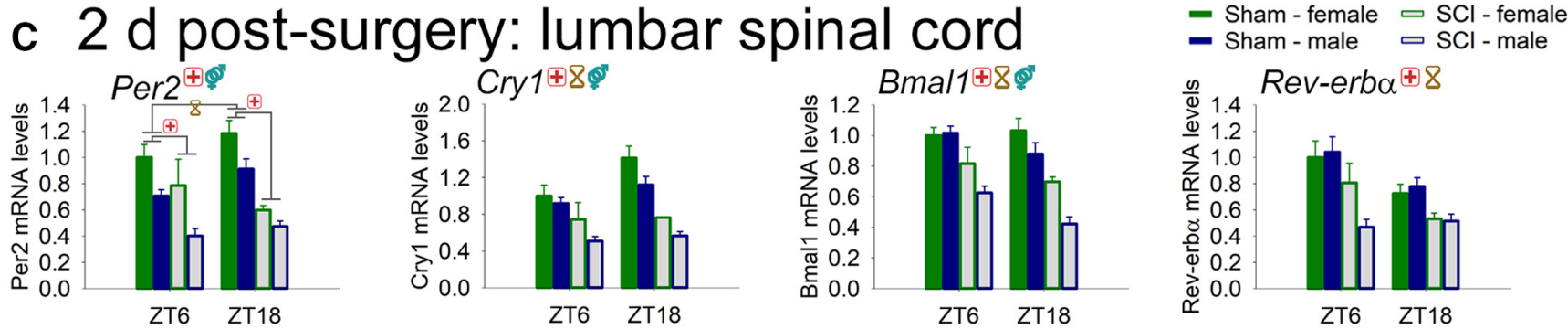

Figure 7. Diurnal regulation of clock genes in spinal cord from uninjured rats and from sham/SCI rats at $2 \mathrm{~d}$ postsurgery. $\boldsymbol{A}$, Female and male rat spinal cords express clock genes, and clock gene expression varies through the day. Per2, Cry 1, Bmal1, and Rev-erba displayed rhythmic expression in the spinal cord. Females generally expressed higher levels of expression of clock genes. $\boldsymbol{B}$, SCI disrupts clock gene expression at the lesion epicenter. Clock gene expression at ZT6 and ZT18 was assessed. Sham spinal cords showed clock gene variation between the two time points (e.g., Per2, Cry1, and Rev-erba). After SCI, injury epicenters showed strongly reduced expression and ablated diurnal variation of these four clock genes, suggesting circadian disruption. $\boldsymbol{C}, \mathrm{SCl}$ disrupts clock gene expression in spinal cord distal to injury. The lumbar spinal cord, which was not directly injured by contusion, showed decreased expression of the four clock genes examined in $\mathrm{SCl}$ vs sham rats. There were also time-of-day differences for all genes presented, and a significant main effect of sex for Per2, Cry1, and Bmal1. Black indicates that females or males for that gene show significant rhythm; red + indicates injury difference (sham vs SCl), $p<0.05$; yellow hourglass indicates time difference, $p<0.05$; blue gender symbol indicates sex difference, $p<0.05$. Symbols at the top of each graph indicate the significant main effect; symbols above/below data indicate significant interactions.

Table 2 : Expression of additional clock (Per1, Clock) and inflammatory (Iba1, Mhc II) genes at $2 \mathrm{~d}$ postsurgery in the lesion epicenter and lumbar spinal cord (data only for genes not shown in figures)

\begin{tabular}{|c|c|c|c|c|c|c|c|c|c|c|}
\hline & Female & & & & Male & & & & Significant & \\
\hline & ZT6 & & ZT18 & & ZT6 & & ZT18 & & differences & \\
\hline $\begin{array}{l}\text { Gene } \\
\text { Per1 }\end{array}$ & Sham & $\mathrm{SCl}$ & Sham & $\mathrm{SCl}$ & Sham & $\mathrm{SCl}$ & Sham & $\mathrm{SCl}$ & Main effect & Interactions \\
\hline Lesion & $1.00 \pm 0.10$ & $0.39 \pm 0.06$ & $1.19 \pm 0.07$ & $0.23 \pm 0.03$ & $1.01 \pm 0.17$ & $0.35 \pm 0.06$ & $2.01 \pm 0.57$ & $0.34 \pm 0.01$ & SCI: ZT6 + 18 & Sham $\times Z T$ \\
\hline $\begin{array}{l}\text { Lumbar } \\
\text { Clock }\end{array}$ & $1.00 \pm 0.05$ & $1.04 \pm 0.29$ & $0.97 \pm 0.09$ & $0.70 \pm 0.03$ & $0.78 \pm 0.08$ & $0.57 \pm 0.07$ & $0.84 \pm 0.12$ & $0.50 \pm 0.02$ & SCl, sex & N.S. \\
\hline Lesion & $1.00 \pm 0.16$ & $0.32 \pm 0.03$ & $1.21 \pm 0.18$ & $0.27 \pm 0.04$ & $0.90 \pm 0.18$ & $0.36 \pm 0.09$ & $1.56 \pm 0.33$ & $0.29 \pm 0.03$ & $\mathrm{SCl}$ & Sham $\times Z \mathrm{ZT}$ \\
\hline $\begin{array}{l}\text { Lumbar } \\
\text { Iba1 }\end{array}$ & $1.00 \pm 0.03$ & $0.71 \pm 0.10$ & $1.07 \pm 0.06$ & $0.64 \pm 0.04$ & $0.94 \pm 0.07$ & $0.53 \pm 0.07$ & $0.83 \pm 0.08$ & $0.45 \pm 0.04$ & $\mathrm{SCl}$ & Sham $\times \mathrm{ZT}$ \\
\hline Lesion & $1.00 \pm 0.21$ & $0.75 \pm 0.03$ & $0.86 \pm 0.08$ & $0.93 \pm 0.09$ & $0.69 \pm 0.09$ & $0.41 \pm 0.07$ & $0.59 \pm 0.04$ & $0.78 \pm 0.14$ & Sex & $\mathrm{SCl} \times \mathrm{ZT} ; \mathrm{ZT} 6 \times$ inj. \\
\hline $\begin{array}{l}\text { Lumbar } \\
\text { Mhc II }\end{array}$ & $1.00 \pm 0.07$ & $1.36 \pm 0.04$ & $0.96 \pm 0.08$ & $1.38 \pm 0.13$ & $1.32 \pm 0.05$ & $2.06 \pm 0.45$ & $1.23 \pm 0.12$ & $1.54 \pm 0.18$ & N.S. & N.S. \\
\hline Lesion & $1.00 \pm 0.17$ & $0.21 \pm 0.05$ & $0.82 \pm 0.09$ & $0.21 \pm 0.03$ & $0.65 \pm 0.14$ & $0.23 \pm 0.05$ & $0.79 \pm 0.14$ & $0.22 \pm 0.05$ & $\mathrm{SCl}$ & N.S. \\
\hline Lumbar & $1.00 \pm 0.19$ & $0.50 \pm 0.05$ & $0.54 \pm 0.21$ & $0.54 \pm 0.18$ & $1.59 \pm 0.38$ & $0.86 \pm 0.14$ & $1.09 \pm 0.30$ & $0.54 \pm 0.11$ & SCl, sex & N.S. \\
\hline
\end{tabular}

For statistical comparisons (far right column): $\mathrm{SCl}$, significant main effect of $\mathrm{SCl}$ vs sham; ZT, significant main effect of time (ZT6 vs ZT18); sex, significant main effect of sex; Sham $\times$ ZT, significant interaction between sham and ZT; N.S., no significant difference. 
A Uninjured: spinal cord
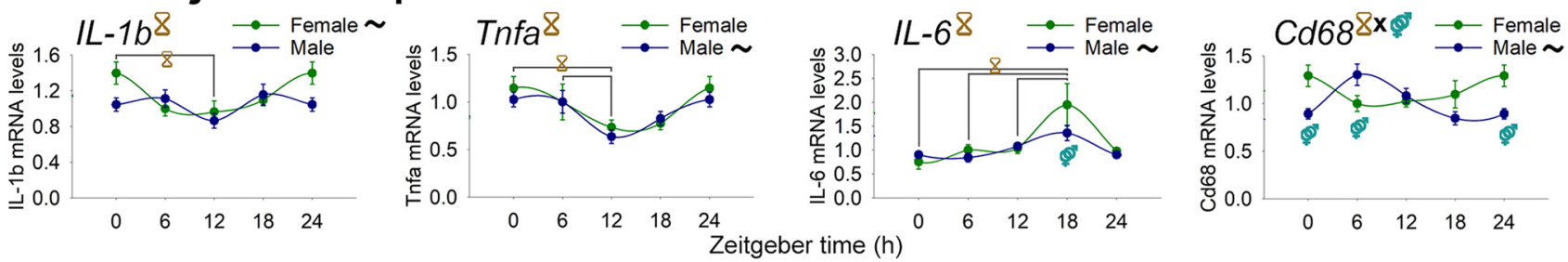

\section{в 2 d post-surgery: lesion epicenter}
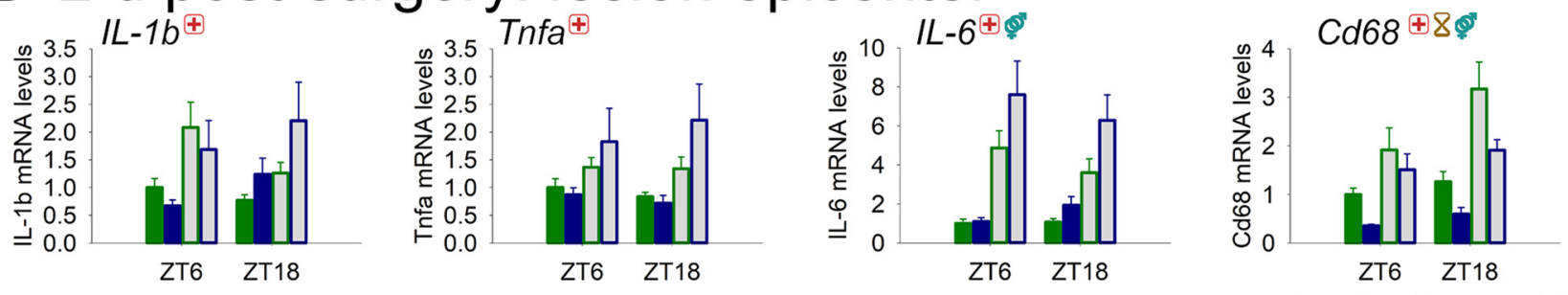

c 2 d post-surgery: lumbar spinal cord
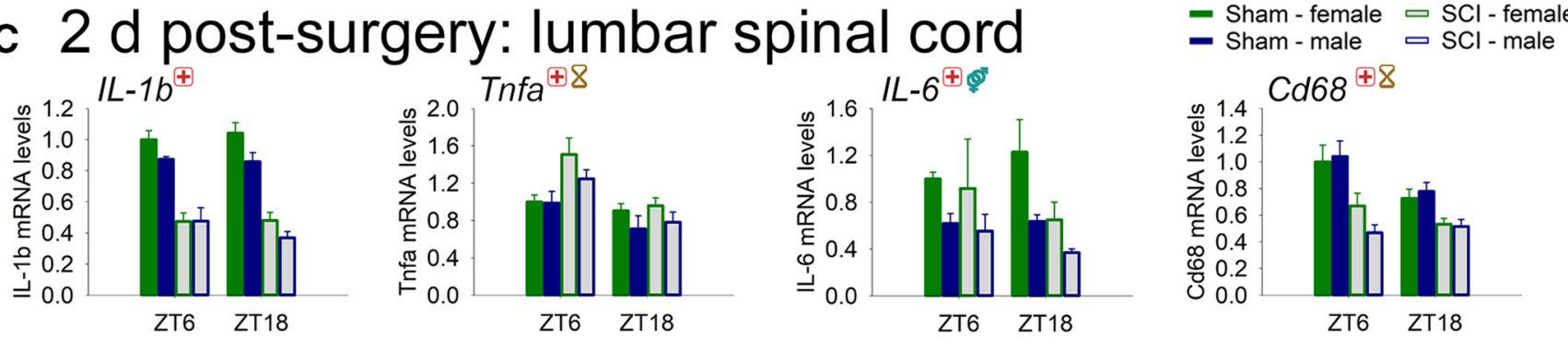

Figure 8. Diurnal regulation of inflammatory genes in spinal cord from uninjured rats, and from sham/SCI rats at $2 \mathrm{~d}$ postsurgery. $\boldsymbol{A}$ Female and male rat spinal cord expression of inflammatory genes varies through the day. IL-1b, Tnfa, and Cd68 displayed time-of-day expression differences in the spinal cord. Rhythmic expression was observed in IL-1b (females), Tnfa (males), IL-6 (males), and Cd68 (males). Sex affected intraspinal IL-6 and Cd68 gene expression. $\boldsymbol{B}, \mathrm{SCl}$ alters inflammatory gene expression at the lesion epicenter. SCl increased expression of $I L-1 b$, Tnfa, IL-6, and Cd68 expression. Epicentre IL-6 was also regulated by sex, and Cd68 was also regulated by $\mathrm{ZT}$ and by sex. $\mathbf{C}, \mathrm{SCl}$ modulates inflammatory gene expression in spinal cord distal to injury. $\mathrm{SCl}$ reduced lumbar spinal cord expression of $I L 1 b, I L-6$, and $C d 68$, and increased the expression of Tnfa. There were also significant main effects of ZT (Tnfa, Cd68; both lower at ZT18) and sex (IL-6; females higher than males). Black indicates that females or males for that gene show significant rhythm; red + indicates injury difference (sham vs $\mathrm{SCl}$ ), $p<0.05$; yellow hourglass indicates time difference, $p<$ 0.05; blue gender symbol indicates sex difference, $p<0.05$. Symbols at the top of each graph indicates significant main effect; symbols above/below data indicate significant interactions.

the epicenter, but was downregulated in the lumbar spinal cord $\left[F_{(1,44)}=32.6\right.$ and $F_{(1,29)}=31.2$, respectively; both $p$ $<0.001$; main effects; also main effect of time (epicenter and lumbar) and sex (epicenter); $\mathrm{SCl}$ also altered intraspinal expression of Iba1, an RNA expressed by microglia/ macrophages, and Mhc II, an antigen-presenting molecule expressed by microglia/macrophages; Table 2]. Thus, $\mathrm{SCl}$ robustly dysregulated intraspinal clock and inflammatory gene expression.

\section{Discussion}

This study used female and male rats to determine whether SCl dysregulated acute-to-chronic physiologic and behavioral rhythms and related molecular outputs. Moderate T8 spinal cord contusion dysregulated plasma CORT-a key humoral output of and feedback signal for the circadian system-particularly at 2 and $7 \mathrm{~d}$ postsurgery. In addition, $\mathrm{SCl}$ dampened diurnal rhythms in locomotor activity and body temperature. SCl strongly decreased the expression of several clock genes in the epicenter and lumbar spinal cord, and also altered the expression of intraspinal inflammatory genes at two times of day. Therefore, moderate $\mathrm{SCl}$ in a rat model severely disrupts daily rhythms in CORT, activity, body temperature, and intraspinal gene expression. The physiologic parameters studied gradually reacquired more typical daily rhythms over time. Our results suggest that moderate contusion $\mathrm{SCl}$ causes widespread, transient disruption of physiologic homeostasis (Fig. 9).

\section{Locomotor recovery after $\mathrm{SCI}$}

As expected, rats with $\mathrm{SCl}$ showed a substantial deficit in hindlimb movement at $1 \mathrm{dpi}$, and the rats recovered frequent stepping by the chronic $42 \mathrm{dpi}$ time point. Locomotor recovery had not previously been assessed in this model (a T8 150 kdyn contusion with $1 \mathrm{~s}$ dwell; Putatunda et al., 2014; Gaudet et al., 2017; Hook et al., 2017). Interestingly, the post-SCI locomotor recovery presented here complements the findings of others: our average BBB score of 10.6 in female 42 dpi rats supports that this injury severity is between the severities reported previ- 


\section{A Healthy: circadian system in homeostasis}

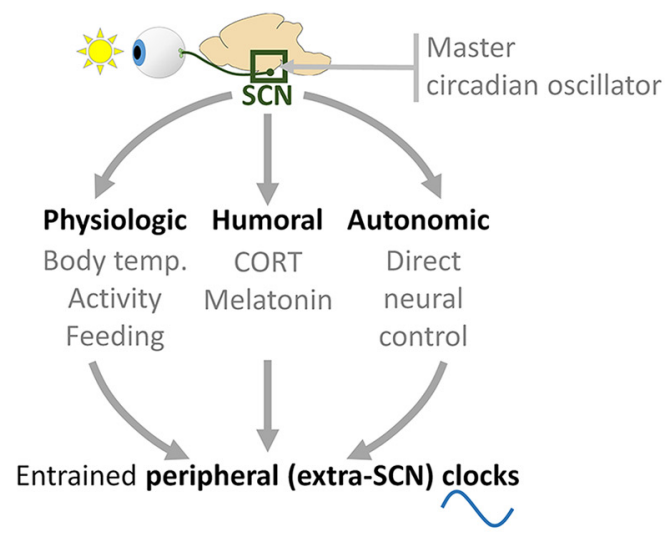

B Post-SCl: Disrupted circadian system

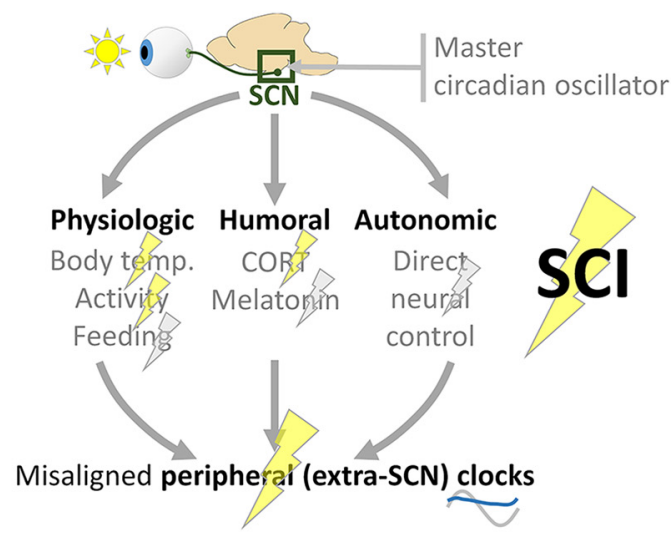

Figure 9. SCl disrupts diurnal rhythms. $\boldsymbol{A}$, Diurnal rhythm control under homeostatic conditions. Initial circadian input occurs via light activating specialized retinal ganglion cells that project directly to the SCN. The SCN is the master circadian oscillator; in turn, this regulates extra-SCN ("peripheral") rhythms via direct and indirect routes. The SCN controls peripheral clocks directly via autonomic control (sympathetic and parasympathetic innervation), whereas the SCN controls peripheral clocks indirectly through the regulation of physiologic and humoral factors. Appropriately entrained clocks throughout the body (likely every cell) optimize organismal performance for time of day. B, Diurnal rhythm control is disrupted by SCl. Our data suggest that $\mathrm{SCl}$ disrupts rhythms of key zeitgeber times, including body temperature, activity, and CORT level (yellow bolts), which could disrupt peripheral clock entrainment. In addition, data from other groups suggest that $\mathrm{SCl}$ also disrupts additional entraining factors (e.g., feeding, melatonin, and autonomic input; gray bolts). Ultimately, prolonged SCl-elicited disruption of these entraining factors could contribute to the loss of homeostasis and suboptimal repair.

ously (vs 150 and 200 kdyn with 0 s dwell; Scheff et al., 2003).

\section{$\mathrm{SCl}$ disrupts diurnal rhythms and physiologic homeostasis}

Diurnal rhythms help to optimize organism function across the day; thus, disrupting diurnal rhythms likely shifts the physiology of an animal away from homeostasis. Prolonged diurnal disruptions have detrimental effects for the individual. Here, we identify $\mathrm{SCl}$ as a disruptor of several prominent physiologic rhythms: CORT, core temperature, and activity.

Glucocorticoids are steroid hormones that help to synchronize extra-SCN circadian rhythms (Balsalobre et al., 2000). This is possible because SCN-derived signals entrain CORT rhythms to light and SCN cells lack CORT receptors, whereas most non-SCN cells express CORT receptors. In this manner, CORT can modulate peripheral circadian clocks directly (e.g., CORT-receptor complex drives Per 1 and reduces Rev-erb $\alpha$ transcription; Oster et al., 2006; Dickmeis, 2009; Surjit et al., 2011). CORT is potently upregulated by immune activation and helps to resolve inflammatory responses; however, CORT is also critically involved in stress responses (Frank et al., 2013) and basic homeostatic functions (Nicolaides et al., 2014). Given these roles of CORT in health and pathology, we hypothesized that $\mathrm{SCl}$ would dysregulate CORT rhythms. Indeed, male and female rats with acute SCI had increased CORT levels and disrupted CORT rhythms. Previous work supports our findings: female mice with T9 contusion SCI had acute, transient dysregulation of glucocorticoid rhythms (Lucin et al., 2007), although no sham mice were included. A recent study by Pruss et al. (2017) found that $\mathrm{SCl}$ in mice increased serum CORT levels ( $T 1$
$\mathrm{SCl}>\mathrm{T} 9 \mathrm{SCl}$; 3 dpi CORT with no time of day specified); similarly, humans within $96 \mathrm{~h}$ post-SCl showed increased serum cortisol levels. SCI in mice and humans substantially increases susceptibility to peripheral infection (pneumonia). In mice, SCl-elicited CORT increases could be quenched by removing the major source of systemic CORT, the adrenal glands, but adrenalectomy did not reduce the frequency of pneumonia (Pruss et al., 2017). Interestingly, transplanting denervated adrenal glands into adrenalectomized SCI mice normalized CORT levels and limited susceptibility to pneumonia (Pruss et al., 2017; but also see Oster et al., 2006). Thus, accelerating the recovery of CORT rhythms could help to regain homeostasis, including diurnal rhythms.

We also revealed that daily rhythms in body temperature were significantly altered at acute post-SCl times and gradually recovered. Immediate post-SCl hypothermia lasted $\sim 24 \mathrm{~h}$ (hypothermia not observed in shams). Body temperature acrophase was particularly disrupted in male rats with $\mathrm{SCl}$, which had altered temperature acrophase that persisted through $30 \mathrm{dpi}$. Others also observed SCIelicited temperature arrhythmia in rats (West et al., 2015). Similarly, humans with acute trauma (including SCl) commonly experience hypothermia, which can copresent with other pathologies and lead to death (Kirkpatrick et al., 1999). In humans with chronic SCl, diurnal regulation of core body temperature was disrupted after cervical, but not thoracic, $\mathrm{SCl}$ (although acute post-SCl rhythms were not assessed; Thijssen et al., 2011). Body temperature rhythms help coordinate peripheral circadian rhythms (Buhr et al., 2010); thus, optimizing post-SCl recovery of body temperature rhythms could accelerate the recovery of homeostasis. 
Activity rhythms were transiently dampened by $\mathrm{SCl}$, which could have more widespread implications for the circadian system. For example, timed activity can be used to help strengthen diurnal rhythms: in mice with a mutation in core circadian clock machinery, scheduled (late night) wheel running strengthened molecular and physiologic rhythms (Schroeder et al., 2012). Behavioral activity feeds back to the SCN: exercise in mice suppresses SCN neuron activity, and exercising at the proper time of the cycle increases SCN diurnal rhythm amplitude (van Oosterhout et al., 2012). In humans, exercising at abnormal times (during the night) phase shifts diurnal rhythms (Youngstedt et al., 2016). Therefore, post-SCl diurnal rhythms may be strengthened by optimizing the time of day of key activities, including rehabilitation, social activity, and feeding.

Glucocorticoids, body temperature, and activity modulate circadian oscillators throughout the body, so SClelicited dysregulation could alter daily rhythms more broadly. Indeed, typical diurnal rhythms in body function can be disrupted in humans by SCl (e.g., sleep; Giannoccaro et al., 2013) and by related medical interventions (Li et al., 2011), so expediting the recovery of diurnal rhythms after $\mathrm{SCl}$ could improve neuroprotection and functional outcomes.

It is important to note that we had limited telemetry receivers, so we completed the body temperature and activity transmitter study separately in males and females. In addition, limitations were noted after completing the male study and methods were improved for the female portion (e.g., rats were acclimated to twice-daily handling before surgery), which could have affected the consistency of the results. Despite this, the results were remarkably similar between males and females, both for sham and $\mathrm{SCl}$ rats, and differences existed between sham and $\mathrm{SCl}$ groups. Our experience and data also highlight that typical postsurgery rodent care and behavioral testing in many research laboratories (e.g., twice-daily rodent care during the light/inactive phase) likely further disrupts daily rhythms (as well as sleep), and could be a confound to the factor under study (McEwen, 2006). Future SCl studies could improve their design by having the daily injections and major care immediately before the active phase, and by having a second potential daily care time during the dark phase or at another minimally disruptive time (e.g., using shifted light schedules in animal housing, if helpful). In addition, given that intense rodent care during the beginning of the inactive phase is likely a strong disruptor of rhythms, future studies could compare whether this type of disruption affects anatomic and neurologic outcomes compared with a "circadian-optimized" care schedule. These findings would have translational relevance, since early post-SCl patients in hospitals likely experience excess circadian disruptions (that could be improved with relatively simple interventions).

Another distinction between studies described herein is that the telemetry study was completed with individually housed rats (to enable measuring the temperature and activity of a single rat), whereas all other studies were completed with rats housed in pairs. This is important to note, given that housing rats individually is a stressor (Von Frijtag et al., 2000; Westenbroek et al., 2005) and can impair recovery after CNS injury (Craft et al., 2005; Karelina et al., 2009; Gaudier-Diaz et al., 2017). Furthermore, single housing may reduce relative activity (vs having a cage mate) and therefore likely worsens other aspects of recovery (e.g., locomotor recovery; Van Meeteren et al., 2003).

\section{$\mathrm{SCl}$ alters intraspinal expression and diurnal regulation of clock and inflammatory genes}

At 2 d postsurgery, SCl remarkably reduced the expression of clock genes observed in the lesion epicenter, and a more modest (but significant) decrease also occurred in the lumbar spinal cord. In the lesion epicenter, this is likely affected by altered cell composition: sham T8 spinal cords contain typical CNS cellular constituents, whereas SCI T8 epicenters include various activated immune, glial, and other cells (Gaudet and Fonken, 2018). Epicenterlocalized cells could have different clock gene levels that cause the massive decrease observed. Another possibility is that $\mathrm{SCl}$ dysregulates a finely tuned circadian and inflammatory gene expression network: immune cellspecific circadian gene dysregulation can provoke inflammatory responses (Nguyen et al., 2013; Fonken et al., 2016; Segal et al., 2018); conversely, the induction of cytokines such as TNF- $\alpha$ and IL- $1 \beta$ can suppress the expression and/or function of circadian genes (Cavadini et al., 2007). Indeed, intraspinal Tnfa and IL-1b diurnal regulation inversely correlated with Per2 expression, both in uninjured spinal cord and in the SCl epicenter. Similarly, Rev-erb $\alpha$ reduces IL-6 expression (Gibbs et al., 2012); here, diurnal variation in Rev-erb $\alpha$ and IL-6 levels were inversely related in uninjured spinal cord, and the SCIelicited decrease in epicenter Rev-erb $\alpha$ paralleled an increase in $I L-6$. These findings underscore the potential relevance of clock and inflammatory gene cross talk. In addition, $\mathrm{SCl}$ downregulated clock genes even distal to lesion in lumbar spinal cord, where cell infiltration likely has limited influence. Overall, decreased and arrhythmic clock gene expression by $\mathrm{SCl}$ could broadly regulate immune and homeostatic function in the CNS.

Inflammatory gene expression was differentially affected by SCl in epicenter and lumbar spinal cord. In the epicenter, most genes assessed were upregulated; conversely, most genes assessed in the lumbar spinal cord were downregulated. L4-L5 spinal cord was chosen as a distal spinal cord site because it integrates hindpaw nociceptive information. At later times post-SCl, excess below-level intraspinal inflammation likely contributes to SCl-elicited neuropathic pain (Hains and Waxman, 2006; Detloff et al., 2008), and we found that this contusion model causes neuropathic pain symptoms by $14 \mathrm{dpi}$ in female and male rats (Gaudet et al., 2017). The reduced expression of inflammatory markers at 2 dpi may represent an initial remote intraspinal dampening of the immune response, which may precede chronic neuroinflammation that exacerbates neuropathic pain and pathology. 
Here, two time points [middle of the light (ZT6) and dark (ZT18) phase] were used to assess clock and inflammatory gene expression at $2 \mathrm{~d}$ post-SCl. This is a limitation of the study, since with two time points it is not possible to make broader conclusions about the effects of $\mathrm{SCl}$ on circadian phase, amplitude, and average expression. Future studies could examine the expression at additional times of day. Further, the disruption of circadian outputs persisted beyond $2 \mathrm{dpi}$, including rhythms of serum CORT, body temperature, and activity (all were disrupted until at least $7 \mathrm{dpi}$ ), yet our study only assessed gene expression changes at 2 d postsurgery. Gene expression was assessed at $2 \mathrm{~d}$ postsurgery because robust changes in the circadian system were seen at this time, and because early changes in lesion pathology and inflammation likely have strong effects on recovery trajectory (Noble et al., 2002; Kigerl et al., 2009; Gaudet et al., 2018; McCreedy et al., 2018). It is also important, however, to understand how clock and inflammatory gene patterns shift through subacute and chronic times postsurgery. In the future, studying circadian gene expression changes at additional times post-SCl would provide more information about the robustness and duration of the effects of $\mathrm{SCl}$ on the circadian system.

\section{Future directions}

Our study highlights that $\mathrm{SCl}$ disrupts whole-body functions, yet unresolved questions remain about post-SCI circadian disruption and related potential therapies. As shown in Figure 9, SCl alters the regulation of several circadian outputs. Daily rhythms are entrained by light input to the retina, influencing the SCN, which is likely protected from changes caused by $\mathrm{SCl}$ [e.g., unlike most cells of the body, SCN neurons lack CORT receptors; Balsalobre et al., 2000; Woodruff et al., 2016). However, peripheral rhythms are synchronized and entrained by other circadian oscillators, including CORT, body temperature, activity, and autonomic circuits (Buijs et al., 2016), that are perturbed by SCl. Therefore, the disruption of circadian outputs could contribute to more widespread circadian disruption throughout the body. Here, a moderate T8 spinal cord contusion was used; future studies could establish whether more severe injuries or injuries at other spinal levels (e.g., cervical or high thoracic, which would more strongly perturb autonomic function; Inskip et al., 2009) differentially alter postinjury circadian dynamics. In addition, our study did not address whether circadian disruption was simply a result of injury, or whether disruption itself further exacerbated outcomes. Future studies could determine whether amplifying post-SCI rhythms using, for example, timed exercise, feeding, light/ dark schedule manipulations, and injections of circadianrelated drugs, could improve recovery measures (discussed more below). The strengthening of post-SCI rhythms could also influence other long-term recovery measures, such as survival, neuroprotection, chronic pain, autonomic function, and general health. Further, since altering circadian rhythms affects other aspects of metabolism, metabolic cage telemetry and calorimetry (Gaudet et al., 2016) could reveal whether boosting post-SCl rhythms improves short-term and long-term metabolic health. Finally, to better understand the effect of $\mathrm{SCl}$ on circadian rhythms, $\mathrm{SCl}$ researchers could adopt other models and strategies frequently used in circadian research, such as the PER::/uciferase transgenic rodent, which uses the clock gene promoter from Per to express the bioluminescent luciferase gene and enables studying rhythm synchrony/dysregulation in vitro (Yamazaki et al., 2000) and in vivo (Tahara et al., 2012).

If $\mathrm{SCl}$-elicited circadian disruption worsens recovery and metabolism, amplifying diurnal rhythms using entraining strategies soon after injury could expedite recovery (Roenneberg and Merrow, 2016). For instance, improving the darkness of rooms during nights (e.g., minimize brightness of lights/monitors; use red lights and filters) and incorporating bright morning light (e.g., having an outdoor-facing window in the room; Engwall et al., 2014), feeding during the day (Stokkan et al., 2001; Fonken et al., 2010), and optimizing the time of day for rehabilitation/ activity (Schroeder et al., 2012) could improve sleep-wake cycles and re-entrain diurnal rhythms. Using these and other strategies to accelerate post-SCI recovery of homeostasis could boost key early recovery processes and overall postinjury outcomes.

\section{Conclusions}

In conclusion, we used a clinically relevant rat spinal contusion model to assess how $\mathrm{SCl}$ affects circadian dynamics. We established that moderate thoracic $\mathrm{SCl}$ has broad effects on diurnal rhythms, including disrupted rhythms of plasma CORT levels, activity, body temperature, and intraspinal gene expression. SCl caused robust diurnal rhythm disruption at acute post-SCI times (2 and 7 $\mathrm{dpi}$; across various circadian measures); $\mathrm{SCl}$ rats recovered more typical diurnal rhythmicity by subacute-tochronic times (14-42 dpi). SCl-associated disruption of these key regulators of physiologic homeostasis may feed back to impede $\mathrm{SCl}$ recovery. Future discovery and clinical SCl studies could incorporate measures of circadian function, which may reveal post-SCl "chronotherapies" that help to regain homeostasis and improve recovery.

\section{References}

Alan N, Ramer LM, Inskip JA, Golbidi S, Ramer MS, Laher I, Krassioukov AV (2010) Recurrent autonomic dysreflexia exacerbates vascular dysfunction after spinal cord injury. Spine J 10:11081117. CrossRef

Balsalobre A, Brown SA, Marcacci L, Tronche F, Kellendonk C, Reichardt HM, Schütz G, Schibler U (2000) Resetting of circadian time in peripheral tissues by glucocorticoid signaling. Science 289:2344-2347. Medline

Basso DM, Beattie MS, Bresnahan JC (1995) A sensitive and reliable locomotor rating scale for open field testing in rats. J Neurotrauma 12:1-21. CrossRef Medline

Bedrosian TA, Fonken LK, Nelson RJ (2016) Endocrine effects of circadian disruption. Annu Rev Physiol 78:109-131. CrossRef Medline

Buhr ED, Yoo SH, Takahashi JS (2010) Temperature as a universal resetting cue for mammalian circadian oscillators. Science 330: 379-385. CrossRef

Buijs FN, León-Mercado L, Guzmán-Ruiz M, Guerrero-Vargas NN, Romo-Nava F, Buijs RM (2016) The circadian system: a regulatory feedback network of periphery and brain. Physiology (Bethesda) 31:170-181. CrossRef 
Cavadini G, Petrzilka S, Kohler P, Jud C, Tobler I, Birchler T, Fontana A (2007) TNF-alpha suppresses the expression of clock genes by interfering with E-box-mediated transcription. Proc Natl Acad Sci U S A 104:12843-12848. CrossRef Medline

Cavigelli SA, Monfort SL, Whitney TK, Mechref YS, Novotny M, McClintock MK (2005) Frequent serial fecal corticoid measures from rats reflect circadian and ovarian corticosterone rhythms. J Endocrinol 184:153-163. CrossRef Medline

Cho HJ, Staikopoulos V, Furness JB, Jennings EA (2009) Inflammation-induced increase in hyperpolarization-activated, cyclic nucleotide-gated channel protein in trigeminal ganglion neurons and the effect of buprenorphine. Neuroscience 162:453-461. CrossRef Medline

Craft TK, Glasper ER, McCullough L, Zhang N, Sugo N, Otsuka T, Hurn PD, DeVries AC (2005) Social interaction improves experimental stroke outcome. Stroke 36:2006-2011. CrossRef Medline

Cragg JJ, Ravensbergen HJ, Borisoff JF, Claydon VE (2015) Optimal scaling of weight and waist circumference to height for adiposity and cardiovascular disease risk in individuals with spinal cord injury. Spinal Cord 53:64-68. CrossRef Medline

D'Agostino J, Vaeth GF, Henning SJ (1982) Diurnal rhythm of total and free concentrations of serum corticosterone in the rat. Acta Endocrinol (Copenh) 100:85-90. Medline

Detloff MR, Fisher LC, McGaughy V, Longbrake EE, Popovich PG, Basso DM (2008) Remote activation of microglia and proinflammatory cytokines predict the onset and severity of belowlevel neuropathic pain after spinal cord injury in rats. Exp Neurol 212:337-347. CrossRef Medline

Dickmeis T (2009) Glucocorticoids and the circadian clock. J Endocrinol 200:3-22. CrossRef Medline

Ellis A, Grace PM, Wieseler J, Favret J, Springer K, Skarda B, Ayala M, Hutchinson MR, Falci S, Rice KC, Maier SF, Watkins LR (2016) Morphine amplifies mechanical allodynia via TLR4 in a rat model of spinal cord injury. Brain Behav Immun 58:348-356. CrossRef

Engwall M, Fridh I, Bergbom I, Lindahl B (2014) Let there be light and darkness: findings from a prestudy concerning cycled light in the intensive care unit environment. Crit Care Nurs Q 37:273-298. CrossRef Medline

Farr LA, Campbell-Grossman C, Mack JM (1988) Circadian disruption and surgical recovery. Nurs Res 37:170-175. Medline

Fonken LK, Nelson RJ (2014) The effects of light at night on circadian clocks and metabolism. Endocr Rev 35:648-670. CrossRef Medline

Fonken LK, Workman JL, Walton JC, Weil ZM, Morris JS, Haim A, Nelson RJ (2010) Light at night increases body mass by shifting the time of food intake. Proc Natl Acad Sci U S A 107:1866418669. CrossRef Medline

Fonken LK, Kitsmiller E, Smale L, Nelson RJ (2012) Dim nighttime light impairs cognition and provokes depressive-like responses in a diurnal rodent. J Biol Rhythms 27:319-327. CrossRef

Fonken LK, Frank MG, Kitt MM, Barrientos RM, Watkins LR, Maier SF (2015) Microglia inflammatory responses are controlled by an intrinsic circadian clock. Brain Behav Immun 45:171-179. CrossRef Medline

Fonken LK, Kitt MM, Gaudet AD, Barrientos RM, Watkins LR, Maier SF (2016) Diminished circadian rhythms in hippocampal microglia may contribute to age-related neuroinflammatory sensitization. Neurobiol Aging 47:102-112. CrossRef Medline

Fonken LK, Frank MG, Gaudet AD, D'Angelo HM, Daut RA, Hampson EC, Ayala MT, Watkins LR, Maier SF (2018) Neuroinflammatory priming to stress is differentially regulated in male and female rats. Brain Behav Immun 70:257-267. CrossRef

Frank MG, Watkins LR, Maier SF (2013) Stress-induced glucocorticoids as a neuroendocrine alarm signal of danger. Brain Behav Immun 33:1-6. CrossRef Medline\&

Gärtner K, Büttner D, Döhler K, Friedel R, Lindena J, Trautschold I (1980) Stress response of rats to handling and experimental procedures. Lab Anim 14:267-274. CrossRef Medline

Gaudet AD, Fonken LK (2018) Glial cells shape pathology and repair after spinal cord injury. Neurotherapeutics 15:554-577. CrossRef
Gaudet AD, Sweet DR, Polinski NK, Guan Z, Popovich PG (2015) Galectin-1 in injured rat spinal cord: implications for macrophage phagocytosis and neural repair. Mol Cell Neurosci 64:84-94. CrossRef Medline

Gaudet AD, Fonken LK, Gushchina LV, Aubrecht TG, Maurya SK, Periasamy M, Nelson RJ, Popovich PG (2016) miR-155 deletion in female mice prevents diet-induced obesity. Sci Rep 6:22862. CrossRef Medline

Gaudet AD, Ayala MT, Schleicher WE, Smith EJ, Bateman EM, Maier SF, Watkins LR (2017) Exploring acute-to-chronic neuropathic pain in rats after contusion spinal cord injury. Exp Neurol 295:4654. CrossRef Medline

Gaudet AD, Fonken LK, Watkins LR, Nelson RJ, Popovich PG (2018) MicroRNAs: roles in regulating neuroinflammation. Neuroscientist 24:221-245. CrossRef

Gaudier-Diaz MM, Zhang N, Haines AH, Surbhi Zhou M, DeVries AC (2017) Social interaction modulates the neuroinflammatory response to global cerebral ischemia in male mice. Brain Res 1673: 86-94.

Giannoccaro MP, Moghadam KK, Pizza F, Boriani S, Maraldi NM, Avoni P, Morreale A, Liguori R, Plazzi G (2013) Sleep disorders in patients with spinal cord injury. Sleep Med Rev 17:399-409. CrossRef Medline

Gibbs JE, Blaikley J, Beesley S, Matthews L, Simpson KD, Boyce SH, Farrow SN, Else KJ, Singh D, Ray DW, Loudon AS (2012) The nuclear receptor REV-ERB $\alpha$ mediates circadian regulation of innate immunity through selective regulation of inflammatory cytokines. Proc Natl Acad Sci U S A 109:582-587. CrossRef Medline

Grace PM, Strand KA, Galer EL, Urban DJ, Wang X, Baratta MV, Fabisiak TJ, Anderson ND, Cheng K, Greene LI, Berkelhammer D, Zhang Y, Ellis AL, Yin HH, Campeau S, Rice KC, Roth BL, Maier SF, Watkins LR (2016) Morphine paradoxically prolongs neuropathic pain in rats by amplifying spinal NLRP3 inflammasome activation. Proc Natl Acad Sci U S A 113:E3441-E3450. CrossRef Medline

Hains BC, Waxman SG (2006) Activated microglia contribute to the maintenance of chronic pain after spinal cord injury. J Neurosci 26:4308-4317. CrossRef

Hook MA, Woller SA, Bancroft E, Aceves M, Funk MK, Hartman J, Garraway SM (2017) Neurobiological effects of morphine after spinal cord injury. J Neurotrauma 34:632-644. CrossRef Medline

Inskip JA, Ramer LM, Ramer MS, Krassioukov AV (2009) Autonomic assessment of animals with spinal cord injury: tools, techniques and translation. Spinal Cord 47:2-35. CrossRef Medline

Inskip JA, Ramer LM, Ramer MS, Krassioukov AV, Claydon VE (2012) Spectral analyses of cardiovascular control in rodents with spinal cord injury. J Neurotrauma 29:1638-1649. CrossRef Medline

Jones LM, Legge M, Goulding A (2003) Healthy body mass index values often underestimate body fat in men with spinal cord injury. Arch Phys Med Rehabil 84:1068-1071. Medline

Karelina K, Norman GJ, Zhang N, Morris JS, Peng H, DeVries AC (2009) Social isolation alters neuroinflammatory response to stroke. Proc Natl Acad Sci U S A 106:5895-5900. CrossRef Medline

Kigerl KA, Gensel JC, Ankeny DP, Alexander JK, Donnelly DJ, Popovich PG (2009) Identification of two distinct macrophage subsets with divergent effects causing either neurotoxicity or regeneration in the injured mouse spinal cord. J Neurosci 29:13435-13444. CrossRef Medline

Kirkpatrick AW, Chun R, Brown R, Simons RK (1999) Hypothermia and the trauma patient. Can J Surg 42:333-343. Medline

Li D, Ma S, Guo D, Cheng T, Li H, Tian Y, Li J, Guan F, Yang B, Wang $J$ (2016) Environmental circadian disruption worsens neurologic impairment and inhibits hippocampal neurogenesis in adult rats after traumatic brain injury. Cell Mol Neurobiol 36:1045-1055. CrossRef Medline

Li SY, Wang TJ, Vivienne Wu SF, Liang SY, Tung HH (2011) Efficacy of controlling night-time noise and activities to improve patients' sleep quality in a surgical intensive care unit. J Clin Nurs 20:396407. CrossRef 
Lucin KM, Sanders VM, Jones TB, Malarkey WB, Popovich PG (2007) Impaired antibody synthesis after spinal cord injury is level dependent and is due to sympathetic nervous system dysregulation. Exp Neurol 207:75-84. CrossRef Medline

McCreedy DA, Lee S, Sontag CJ, Weinstein P, Olivas AD, Martinez AF, Fandel TM, Trivedi A, Lowell CA, Rosen SD, Noble-Haeusslein LJ (2018) Early targeting of L-selectin on leukocytes promotes recovery after spinal cord injury, implicating novel mechanisms of pathogenesis. eNeuro 5:ENEURO.0101-18.2018. CrossRef

McEwen BS (2006) Sleep deprivation as a neurobiologic and physiologic stressor: allostasis and allostatic load. Metabolism 55:S20S23. CrossRef

Nguyen KD, Fentress SJ, Quu Y, Yun K, Cox JS, Chawla A (2013) Circadian gene Bmal1 regulates diurnal oscillations of Ly6C(hi) inflammatory monocytes. Science 341:1483-1488. CrossRef

Nicolaides NC, Charmandari E, Chrousos GP, Kino T (2014) Circadian endocrine rhythms: the hypothalamic-pituitary-adrenal axis and its actions. Ann N Y Acad Sci 1318:71-80. CrossRef Medline

Noble LJ, Donovan F, Igarashi T, Goussev S, Werb Z (2002) Matrix metalloproteinases limit functional recovery after spinal cord injury by modulation of early vascular events. J Neurosci 22:7526-7535. CrossRef

Oster H, Damerow S, Kiessling S, Jakubcakova V, Abraham D, Tian J, Hoffmann MW, Eichele G (2006) The circadian rhythm of glucocorticoids is regulated by a gating mechanism residing in the adrenal cortical clock. Cell Metab 4:163-173. CrossRef Medline

Pruss $\mathrm{H}$, Tedeschi A, Thiriot A, Lynch L, Loughhead SM, Stutte S, Mazo IB, Kopp MA, Brommer B, Blex C, Geurtz LC, Liebscher T, Niedeggen A, Dirnagl U, Bradke F, Volz MS, DeVivo MJ, Chen Y, von Andrian UH, Schwab JM (2017) Spinal cord injury-induced immunodeficiency is mediated by a sympathetic-neuroendocrine adrenal reflex. Nat Neurosci 20:1549-1559. CrossRef

Putatunda R, Hala TJ, Chin J, Lepore AC (2014) Chronic at-level thermal hyperalgesia following rat cervical contusion spinal cord injury is accompanied by neuronal and astrocyte activation and loss of the astrocyte glutamate transporter, GLT1, in superficial dorsal horn. Brain Res 1581:64-79. CrossRef Medline

Reebs SG, Mrosovsky N (1989) Effects of induced wheel running on the circadian activity rhythms of Syrian hamsters: entrainment and phase response curve. J Biol Rhythms 4:39-48. CrossRef Medline

Roenneberg T, Merrow M (2016) The circadian clock and human health. Curr Biol 26:R432-R443. CrossRef Medline

Sauerbeck AD, Laws JL, Bandaru VV, Popovich PG, Haughey NJ, McTigue DM (2015) Spinal cord injury causes chronic liver pathology in rats. J Neurotrauma 32:159-169. CrossRef Medline

Scheff SW, Rabchevsky AG, Fugaccia I, Main JA, Lumpp JE Jr. (2003) Experimental modeling of spinal cord injury: characterization of a force-defined injury device. J Neurotrauma 20:179-193. CrossRef

Schindelin J, Arganda-Carreras I, Frise E, Kaynig V, Longair M, Pietzsch T, Preibisch S, Rueden C, Saalfeld S, Schmid B, Tinevez JY, White DJ, Hartenstein V, Eliceiri K, Tomancak P, Cardona A (2012) Fiji: an open-source platform for biological-image analysis. Nat Methods 9:676-682. CrossRef Medline

Schroeder AM, Truong D, Loh DH, Jordan MC, Roos KP, Colwell CS (2012) Voluntary scheduled exercise alters diurnal rhythms of behaviour, physiology and gene expression in wild-type and vasoactive intestinal peptide-deficient mice. J Physiol 590:6213-6226. CrossRef Medline
Schwab JM, Zhang Y, Kopp MA, Brommer B, Popovich PG (2014) The paradox of chronic neuroinflammation, systemic immune suppression, autoimmunity after traumatic chronic spinal cord injury. Exp Neurol 258:121-129. CrossRef Medline

Segal JP, Tresidder KA, Bhatt C, Gilron I, Ghasemlou N (2018) Circadian control of pain and neuroinflammation. J Neurosci Res 96:1002-1020. CrossRef Medline

Stevens RG, Brainard GC, Blask DE, Lockley SW, Motta ME (2014) Breast cancer and circadian disruption from electric lighting in the modern world. CA Cancer J Clin 64:207-218. CrossRef

Stokkan KA, Yamazaki S, Tei H, Sakaki Y, Menaker M (2001) Entrainment of the circadian clock in the liver by feeding. Science 291:490-493. CrossRef Medline

Surjit M, Ganti KP, Mukherji A, Ye T, Hua G, Metzger D, Li M, Chambon $P$ (2011) Widespread negative response elements mediate direct repression by agonist-liganded glucocorticoid receptor. Cell 145:224-241. CrossRef Medline

Tahara Y, Kuroda H, Saito K, Nakajima Y, Kubo Y, Ohnishi N, Seo Y, Otsuka M, Fuse Y, Ohura Y, Komatsu T, Moriya Y, Okada S, Furutani N, Hirao A, Horikawa K, Kudo T, Shibata S (2012) In vivo monitoring of peripheral circadian clocks in the mouse. Curr Biol 22:1029-1034. CrossRef Medline

Tahara Y, Aoyama S, Shibata S (2017) The mammalian circadian clock and its entrainment by stress and exercise. J Physiol Sci 67:1-10. CrossRef Medline

Thijssen DH, Eijsvogels TM, Hesse M, Ballak DB, Atkinson G, Hopman MT (2011) The effects of thoracic and cervical spinal cord lesions on the circadian rhythm of core body temperature. Chronobiol Int 28:146-154. CrossRef Medline

Van Meeteren NL, Eggers R, Lankhorst AJ, Gispen WH, Hamers FP (2003) Locomotor recovery after spinal cord contusion injury in rats is improved by spontaneous exercise. J Neurotrauma 20:1029 1037. CrossRef Medline

van Oosterhout F, Lucassen EA, Houben T, vanderLeest HT, Antle MC, Meijer JH (2012) Amplitude of the SCN clock enhanced by the behavioral activity rhythm. PLoS One 7:e39693. CrossRef Medline

Von Frijtag JC, Reijmers LG, Van der Harst JE, Leus IE, Van den Bos R, Spruijt BM (2000) Defeat followed by individual housing results in long-term impaired reward- and cognition-related behaviours in rats. Behav Brain Res 117:137-146. Medline

West CR, Popok D, Crawford MA, Krassioukov AV (2015) Characterizing the temporal development of cardiovascular dysfunction in response to spinal cord injury. J Neurotrauma 32:922-930. CrossRef Medline

Westenbroek C, Snijders TA, den Boer JA, Gerrits M, Fokkema DS, Ter Horst GJ (2005) Pair-housing of male and female rats during chronic stress exposure results in gender-specific behavioral responses. Horm Behav 47:620-628. CrossRef Medline

Woodruff ER, Chun LE, Hinds LR, Spencer RL (2016) Diurnal corticosterone presence and phase modulate clock gene expression in the male rat prefrontal cortex. Endocrinology 157:1522-1534. CrossRef Medline

Yamazaki S, Numano R, Abe M, Hida A, Takahashi R, Ueda M, Block GD, Sakaki Y, Menaker M, Tei H (2000) Resetting central and peripheral circadian oscillators in transgenic rats. Science 288: 682-685. CrossRef

Youngstedt SD, Kline CE, Elliott JA, Zielinski MR, Devlin TM, Moore TA (2016) Circadian phase-shifting effects of bright light, exercise, and bright light + exercise. J Circadian Rhythms 14:2. 